Acta Poloniae Historica

107, 2013

PL ISSN 0001-6892

\title{
Zbigniew Dalewski
}

\section{PATTERNS OF DYNASTIC IDENTITY IN THE EARLY MIDDLE AGES}

In 929, Henry I, king of the East Franks, issued in Quedlinburg a document whereby, on consent of his son Otto and on request of the bishops and the secular magnates, he bequeathed to his wife Mathilde his numerous possessions, as widow's seat and land. Explaining the rationale behind this act, the King said that his intent was to dispose of his house, with God's help: "domum nostram deo opitulante ordinaliter disponere". ${ }^{1}$

The desire to set the household affairs in order, as expressed in the quoted document, has usually been associated with the decision of 929 to establish Bishop Balderic of Utrecht, the patron and protector of his youngest son Bruno, with a view of his career as a clergyman, ${ }^{2}$ and to commence, at that very time, his endeavours for soliciting the daughter of the English king Aethelstan as a match for his eldest son Otto, begotten from his marriage to Mathilde. ${ }^{3}$ A new arrangement of the relationships within the royal family, which evolved from those events, was supposedly reflected in an entry, also dated 929, in the Reichenau Abbey's book of confraternity, naming the members of Henry's family and distinguishing Otto with a royal title, along with Henry and Mathilde. ${ }^{4}$

${ }^{1}$ Conradi I., Heinrici I. et Ottonis I. Diplomata, ed. Theodor von Sickel, MGH Diplomata regum et imperatorum Germaniae, i (Hanover, 1879-84), Heinrich I., no. 20, pp. 55-6.

${ }^{2}$ Ruotgeri Vita Brunonis Archiepiscopi Coloniensis, ed. Irene Ott, MGH Scriptores rerum Germanicarum, Nova Series (hereafter: SS rer. Germ. N.S.), x (Weimar, 1951), chap. 4, p. 5.

${ }^{3}$ See Karl Leyser, 'Die Ottonen und Wessex', Frühmittelalterliche Studien, xvii (1983), 73-97; Wolfgang Georgi, 'Bischof Keonwald von Worcester und die Heirat Ottos I. mit Edgitha im Jahre 929', Historisches Jahrbuch, 115 (1995), 1-40.

${ }^{4}$ Das Verbrüderungsbuch der Abtei Reichenau, ed. Johanne Autenrieth, Dieter Geuenich, and Karl Schmid, MGH Libri memoriales et Necrologia, Nova Series, i 
Essential about the actions carried out by Henry in 929 was, in the first place, his striving for settling the succession to the throne, bestowing a dynastic character on the power wielded by him, and keeping this power by members of his family. As was then resolved, the royal authority was not to be apportioned to all the sons of Henry. The kingship was to be allocated to one of them - that is, Otto, whom his father had appointed the heir to the throne, whilst the other sons were deprived of a share in it. ${ }^{5} \mathrm{~A}$ new dynasty, built by Henry, was thus designed as restricted to a single line of the royal family, with a majority of his relatives, including most of his sons, remaining outside it. According to what was decided in 929, seven years later - in 936, after Henry I's death, Otto I took over the royal rule by himself, and was solemnly crowned king in Aachen. ${ }^{6}$

In 946 , Otto I himself fully referred to the dynastic model shaped in consequence of Henry I's decision. With no concern for the royal aspirations of his younger brother Henry, he resolved to appoint his sixteenth-year-old son Liudolf his successor. ${ }^{7}$ In 961 , on revisiting the succession issue, he neglected his grandson Otto, son of Liudolf (his father died in 955), and was granted consent from the aristocrats to

(Hanover, 1979), 63; see Karl Schmid, 'Neue Quellen zum Verständnis des Adels im 10. Jahrhundert', Zeitschrift für die Geschichte der Oberrheins, cviii (1960), 186 ff.; Gerd Althoff, Amicitiae und Pacta. Bündnis, Einung, Politik und Gebetsgedenken im beginnenden 10. Jahrhundert (Munich, 1992), $107 \mathrm{ff}$.

${ }^{5}$ Karl Schmid, 'Die Thronfolge Ottos des Großen', Zeitschrift der Savigny-Stiftung für Rechtsgeschichte, Germanistische Abteilung, 81 (1964), 80-163; also, see Johannes Laudage, 'Hausrecht und Thronfolge. Überlegungen zur Königserhebung Ottos des Großen und zu den Aufständen Thankmars, Heinrichs und Liudolfs', Historisches Jahrbuch, cxii (1992), 23-71; Hagen Keller, 'Widukinds Bericht über die Aachener Wahl und Krönung Ottos I.', Frühmittelalterliche Studien, xxix (1995), 390-453; Thomas Zotz, 'Wie der Typ des Allein-Herrschers (monarchus) durchgesetzt wurde: um 929', in Bernhard Jussen (ed.), Die Macht des Königs. Herrschaft in Europa vom Frühmittelalter bis in die Neuzeit (Munich, 2005), 90-105; Wolfgang Giese, Heinrich I. Begründer der ottonischen Herrschaft (Darmstadt, 2008), 126 ff.; cf. Hartmut Hoffmann, 'Zur Geschichte Ottos des Großen', Deutsches Archiv für Erforschung des Mittelalters, xxviii (1972), 42-73; idem, 'Ottonische Fragen', ibidem, li (1995), 53-82.

${ }^{6}$ Widukindi monachi Corbeiensis rerum gestarum Saxonicarum libri tres (hereafter: Widukind), ed. Paul Hirsch, MGH Scriptores rerum Germanicarum, in usum scholarum separatim editi (hereafter: SS rer. Germ. in us. schol.), lx (Hanover, 1935), ii. 1, pp. 63-6.

${ }^{7}$ Widukind, iii. 1, p. 104. 
enthrone his own younger son Otto II, delivered by his wife Adelheid. ${ }^{8}$ Similarly, Otto II ordained in 983 that his son Otto III, then three years old, be crowned as a king, not even considering the option that his first cousin Henry the Quarrelsome have any share in the royal rule whatsoever. ${ }^{9}$

The introduction by Henry I, and consistent observance by his successors, of the new order of succession to the throne had its serious consequences and exerted quite an essential impact upon how the ideas of the character of kingship evolved in the Reich, along with the rules of functioning of the Ottonian monarchy's political system. These developments also significantly informed the way the royal dynasty was perceived: a singular branch of the royal family was distinguished, only extending to the first-line agnatic ancestors and descendants, with a clear separation of this branch against a wider circle of closer and more distant relatives, who were thereby deprived of the right to participate in the monarchal power. ${ }^{10}$ This does not to say that the Ottonian rulers would not resort to their relatives' assistance as they exercised their rule. On the contrary: during Otto I's reign, a place of importance in the power system he created fell to both of his brothers - i.e. Bruno, the Cologne archbishop, ${ }^{11}$ and Henry, whom Otto made duke of Bavaria and who, in spite of

${ }^{8}$ Die Regesten des Kaiserreichs unter Heinrich I. und Otto I., ed. Johann F. Böhmer, Emil von Ottenthal, and Hans H. Kaminsky (Regesta Imperii, ii: Sächsisches Haus 919-1024, 1, repr. Hildesheim, 1967), no. 297a; see Gerd Althoff, Die Ottonen. Königsherrschaft ohne Staat (Stuttgart, 2005), 112 ff.; Rudolf Schieffer, 'Otto II. und sein Vater', Frühmittelalterliche Studien, xxxvi (2002), 255-69.

${ }^{9}$ Die Regesten des Kaiserreiches unter Otto II. 955 (973)-983, ed. Johann F. Böhmer and Hans L. Mikoletzky (Regesta Imperii, ii: Sächsisches Haus 919-1024, 2, Vienna, 1950), nos. 898b, 956t, 956u; see Althoff, Die Ottonen, 150 ff.

${ }^{10} \mathrm{Cf}$. Otto I's document issued shortly after his coronation in 936 for the Quedlinburg convent, unambiguously juxtaposing the royal dynasty, generatio, with a broader group of his relatives, cognatio, assigning the authority rights to the former alone; Conradi I., Heinrici I. et Ottonis I. Diplomata, Otto I., no. 1, pp. 89-90; see Schmid, 'Die Thronfolge Ottos des Großen', 126 ff.; Laudage, 'Hausrecht und Thronfolge', $25 \mathrm{ff}$.

${ }^{11}$ See Karl J. Leyser, Rule and Conflict in an Early Medieval Society: Ottonian Saxony (London, 1979), 17; Winfrid Glocker, Die Verwandten der Ottonen und ihre Bedeutung in der Politik. Studien zur Familienpolitik und zur Genealogie des sächsischen Kaiserhauses (Dissertationen zur mittelalterlichen Geschichte, 5, Cologne and Vienna, 1980), 124 ff.; Henry Mayr-Harting, Church and Cosmos in Early Ottonian Germany: The View from Cologne (Oxford, 2007), 43 ff. 
the earlier disputes, not only established a reconciliation with the king but also became one of his closest advisors. ${ }^{12}$ Essential support to Otto's reign, regardless of the tensions occurring between the two men, came from his eldest, and illegitimate, son William, whom he nominated archbishop of Mainz. ${ }^{13}$ Similarly, Otto II was closely bound, in terms of collaboration, with his namesake nephew, son of Liudolf and duke of Svabia and, later, of Bavaria too. ${ }^{14}$ Positions of importance within the power structures were also held by the other relatives of the Ottonian kings. ${ }^{15}$ Close and numerous bonds linking these rulers with their cousins did not efface the differences between them. The royal authority was only meant to be vested in the Ottonian dynasts, while their relatives or cousins could participate in it only if they recognised this fact - and only to the extent they were consented to do so by those very dynasts.

The rules assumed by the Ottonian rulers that determined the order of the throne succession and provided that the royal authority could only be handed over to one son, differed thoroughly from the principles which were referred to, in this respect, by their Carolingian predecessors. The result was that the Ottonian dynasty assumed a shape much diverting from that characteristic of its Carolingian counterpart. Both dynasties were obviously of a patrilineal character. As opposed, however, to the Ottonian dynasty - narrow, vertically oriented and limited to a single representative in each generation, due not only to the biological reasons - the Carolingian one had a much more horizontal structure, so to say. The Carolingians did not restrict the right to throne succession to one of the sons but instead, granted it to all their male descendants. ${ }^{16}$ Putting it in a nutshell, and in much simplification, it may be said that as for the Carolingian dynasty, the

${ }^{12}$ See Glocker, Die Verwandten der Ottonen, 86 ff.; Althoff, Die Ottonen, 86 ff.

${ }^{13}$ See Glocker, Die Verwandten der Ottonen, $135 \mathrm{ff}$.

${ }^{14}$ Althoff, Die Ottonen, $138 \mathrm{ff}$.

${ }^{15}$ See Hagen Keller, 'Reichsstruktur und Herrschaftsauffassung in ottonisch-frühsalischer Zeit', Frühmittelalterliche Studien, xvi (1982), 109 ff.

${ }^{16}$ See, e.g., Gerd Tellenbach, 'Die geistigen und politischen Grundlagen der karolingischen Thronfolge. Zugleich eine Studie über kollektive Willensbildung und kollektives Handeln im neunten Jahrhundert', Frühmittelalterliche Studien, xiii (1979), 184-302; Eugen Ewig, 'Überlegungen zu den merowingischen und karolingischen Teilungen', in Nascita dell'Europa ed Europa carolingia: un'equazzione da verificare: 19-25 aprile 1979, 2 vols. (Settimane di Studio del Centro Italiano di Studi sull'Alto Medioevo, 27, Spoleto, 1981), i, 225-53. 
very fact of being born to the royal family gave the eligibility to lay claims for holding the rank of monarch; with the Ottonians, the royal descent was but a preliminary condition for being situated within the dynasty that was, in a sense, singled out of the royal family.

In the Carolingian period we can also, and quite obviously, encounter the actions aimed at diminishing the number of prospective successors and depriving some members of the ruling family of the right to participate in power. The restrictions primarily affected illegitimate sons who usually were cut out from succession - although no universal governing rule can be referred to in this respect whatsoever. ${ }^{17}$ Such may be the perception of the decision of Pippin of Heristal, who in 717 , following the death of his sons from his marriage to Plectrud, named Drogo and Grimoald, resolved to distribute the authority he held between their own sons, his grandsons: Theudoald, whom he made a mayor of the palace, and Arnulf, whose authority was to extend to the ducatus of Champagne, or even the whole of Austrasia - in disregard of his own illegitimate sons, Charles Martel and Childebrand. ${ }^{18}$ Similarly, Charles Martel - who, in spite of what

${ }^{17}$ See Wilhelm Sickel, 'Das Thronfolgerecht der unehelichen Karolinger', Zeitschrift der Savigny-Stiftung für Rechtsgeschichte, Germanistische Abteilung, xxiv (1903), 110-47; Hans Hagn, Illegitimität und Thronfolge. Zur Thronfolgeproblematik illegitimer Merowinger, Karolinger und Ottonen (Politik im Mittelalter, 5, Neuried, 2006), $59 \mathrm{ff}$.

${ }^{18}$ For promotion of Theudoald as mayor of the palace, see Liber historiae Francorum, ed. Bruno Krusch, MGH Scriptores rerum Merovingicarum, ii (Hanover, 1888), chap. 50, p. 325; Chronicarum quae dicuntur Fredegarii Scholastici libri IV. cum Continuationibus (hereafter: Fredegar, Cont.), ed. Bruno Krusch, ibidem, chap. 7, p. 173. Arnulf's position is only confirmed in the diplomatic material; see Ingrid Heidrich, 'Titulatur und Urkunden der arnulfingischen Hausmeier', Archiv für Diplomatik, Schriftgeschichte, Siegel- und Wappenkunde, xi/xii (1965/6), no. A 6, pp. 239-40; no. A Metz 4, pp. 251-2; Josef Semmler, 'Zur pippinidisch-karolingischen Sukzessionskrise 714-723', Deutsches Archiv für Erforschung des Mittelalters, xxxiii (1977), 1-36; Brigitte Kasten, Königssöhne und Königsherrschaft. Untersuchungen zur Teilhabe am Reich in der Merowinger- und Karolingerzeit (Hanover, 1997), 59 ff.; Sören Kaschke, Die karolingischen Reichsteilungen bis 831. Herrschaftspraxis und Normvorstellungen in zeitgenössischer Sicht (Hamburg, 2006), 76 ff.; cf. Waltraud Joch, 'Karl Martell - Ein minderberechtigter Erbe Pippins?', in Jörg Jarnut, Ulrich Nonn, and Michael Richter (eds.), Karl Martell in seiner Zeit (Beihefte der Francia, 37, Sigmaringen, 1994), 149-69; eadem, Legitimität und Integration. Untersuchungen $z u$ den Anfängen Karl Martells (Historische Studien, 456, Husum, 1999), 11 ff.; Paul Fouracre, The Age of Charles Martel (Harlow, 2000), 40 ff.; Wolfgang Giese, 
his father had decided, finally managed to overtake the rule of the Frankish Kingdom - resolving in 741 the succession issue, removed his three natural sons and granted the right to participate in power only to his three remaining sons: Carloman, Pippin and Grifo, born out of his two marriages. ${ }^{19}$ Also, the actions taken by Charlemagne since the 780s in order to determine the throne succession rules were clearly marked by the striving toward limiting the number of future successors exclusively to the sons from his marriage with Hildegard. This is also how the succession issue was solved by the so-called Divisio regnorum, a decision Charlemagne issued in 806, whereby his empire was supposed to be divided after his death into Hildegard's three sons: Charles, Pippin and Louis the Pious, thus omitting not only Charlemagne's natural sons, then still underage, but also his firstborn Pippin the Hunchback, born out of the surreptitious relationship with Himiltrude. ${ }^{20}$ After Charles's and Pippin's premature deaths, Charlemagne resolved in 813 to promote Louis the Pious, the only still-alive son of Hildegard, to the rank of co-Emperor, and to hand over the power over Italy to his grandson Bernard, Pippin's son. The Emperor's natural sons were ignored this time as well. ${ }^{21}$ Also

'Die designativen Nachfolgeregelungen der Karolinger 714-979', Deutsches Archiv für Erforschung des Mittelalters, lxiv (2008), 439 ff.

${ }^{19}$ Annales Mettenses priores, ed. Bernhard von Simson, MGH SS rer. Germ. in us. schol., x (Hanover and Leipzig, 1905), 32; see Heinz J. Schüssler, 'Die fränkische Reichsteilung von Vieux-Poitiers (742) und die Reform der Kirche in den Teilreichen Karlmanns und Pippins. Zu den Grenzen der Wirksamkeit des Bonifatius', Francia, xiii (1985), 47-112; Kasten, Königssöhne, 102 ff.; Fouracre, The Age of Charles Martel, 155 ff.; Matthias Becher, 'Eine verschleierte Krise. Die Nachfolge Karl Martells 741 und die Anfänge der karolingischen Hofgeschichtsschreibung', in Johannes Laudage (ed.), Von Fakten und Fiktionen. Mittelalterliche Geschichtsdarstellungen und ihre kritische Aufarbeitung (Cologne, 2003), 95-133; Ulrich Nonn, 'Die Nachfolge Karl Martells und die Teilung von Vieux-Poitiers', in Matthias Becher and Jörg Jarnut (eds.), Der Dynastiewechsel von 751. Vorgeschichte, Legitimationsstrategien und Erinnerung (Münster, 2004), 61-73; Roger Collins, 'Pippin III as Mayor of the Palace: the Evidence', in ibidem, 75-91; Kaschke, Die karolingischen Reichsteilungen, 81 ff.; Giese, 'Die designativen Nachfolgeregelungen', $443 \mathrm{ff}$.

20 Divisio regnorum, ed. Alfred Boretius, MGH Capitularia regum Francorum (hereafter: CrF), i (Hanover, 1883), no. 45, pp. 126-30; see, e.g., Peter Classen, 'Karl der Große und die Thronfolge im Frankenreich', in Festschrift Hermann Heimpel, iii (Göttingen, 1972), 109-34; Kasten, Königssöhne, 138 ff.; Kaschke, Die karolingischen Reichsteilungen, $298 \mathrm{ff}$.

${ }^{21}$ Annales regni Francorum (741-829) qui dicuntur Annales Laurissenses maiores et Einhardi, ed. Friedrich Kurze, MGH SS rer. Germ. in us. schol., vi (Hanover, 
in the following generations, the natural sons were usually removed from participating in the succession - be it by their fathers, just to mention the case of Arnulf, Louis the Pious's firstborn, ${ }^{22}$ or Carloman, son of Lothar I, ${ }^{23}$ or by their relatives who strove for taking over their heritage, as was the case with Lothar II's son, Hugh, ${ }^{24}$ or Charles the Fat's son, Bernard, who unsuccessfully sought to have their monarchal rights confirmed. ${ }^{25}$

Accusations of illegitimate origin were not infrequently referred to by the Carolingians in the course of political disputes they waged among themselves in order to discredit the relatives fallen out with them and exclude them thereby from the group of those legitimated to hold power. As a result, the sources produced after Charles Martel seized power emphasise the illegitimacy of Theudoald, Charles's nephew whom he removed from power; ${ }^{26}$ similarly, the accounts related to Louis the Pious indicate that King Bernard of Italy, Louis's nephew, whom his uncle had blinded, was also an illegitimate child. ${ }^{27}$ All the same, the examples such as Charles Martel himself, or Arnulf

1895), 136-8; see Wolfgang Wendling, 'Die Erhebung Ludwigs des Frommen zum Mitkaiser im Jahre 813 und ihre Bedeutung für die Verfassungsgeschichte des Frankenreiches', Frühmittelalterliche Studien, xix (1985), 201-38; Kasten, Königssöhne, 160 ff.; Johannes Fried, 'Elite und Ideologie oder die Nachfolgeordnung Karls des Großen vom Jahre 813', in Régine Le Jan (ed.), La royauté et les élites dans l'Europe carolingienne (début IXe siècle aux environs de 920) (Lille, 1998), 71-109; Giese, 'Die designativen Nachfolgeregelungen', $458 \mathrm{ff.}$

${ }^{22}$ Kasten, Königssöhne, 175.

23 Ibidem, 387.

${ }^{24}$ See Tellenbach, 'Die geistigen und politischen Grundlagen', 286-8; Simon MacLean, Kingship and Politics in the Late Ninth Century: Charles the Fat and the End of the Carolingian Empire (Cambridge, 2003), $149 \mathrm{ff}$.

25 See MacLean, Kingship and Politics, $129 \mathrm{ff}$.

${ }^{26}$ Liber historiae Francorum, chap. 49, p. 324; Fredegar, Cont., chap. 6, p. 172; see Roger Collins, 'Deception and Misrepresentation in Early Eight-Century Historiography: Two Case Studies', in Jarnut, Nonn and Richter (eds.), Karl Martell in seiner Zeit, 235.

27 Theganus, Gesta Hludowici imperatoris, ed. Ernst Tremp, MGH SS rer. Ger. in us. schol., lxiv (Hanover, 1995), chap. 22, p. 210. Charlemagne, Bernard's grandfather, had no doubts about his descent whatsoever, as is proven by the extension of his care to him after his father Pippin died, and by promoting him to kingship; Annales regni Francorum, 136-7; Einhardi Vita Karoli Magni, ed. Oswald Holder-Egger, MGH SS rer. Germ. in us. schol, xxv (Hanover and Leipzig, 1911), chap. 19, p. 24; see Fried, 'Elite und Ideologie', 93 ff. 
of Carinthia who first, in 887, took power over the East-Frankish Kingdom and subsequently was crowned as emperor, in 896, convince us that even in the late eighth century - the time of increasing rigorousness in this respect - illegitimacy did not at all have to imply pushing the individual off his dynasty's realm and completely close the way to participate in his appurtenant authority. ${ }^{28}$ Thus, there is nothing odd in that soon after his takeover after Charlemagne's death, Louis the Pious decided to destine his stepbrothers born from the emperor's illegitimate relationships, who by that time had stayed at the court in Aachen, for the clergy, thus finally frustrating their possible claims for participation in their paternal heritage. ${ }^{29}$ That membership in the broadly-taken Carolingian dynasty - which encompassed not only all the offspring, including natural, of Charlemagne, but also his quite numerous distant relatives - was essentially associated with ideas of the potential to wield a monarchal authority seems to be additionally testified to by the enigmatical record of 'the Astronomer', Louis's biographer. It unambiguously suggests that the milieu of the new emperor, who took over the rule in 814, seriously took into account the possibility that his cousin, count Wala, Charles Martel's grandson, might stand up against Louis, laying his claims to the throne. ${ }^{30}$ Although Wala finally recognised Louis's authority, the emperor, aware that the aspirations of his cousin, distinguished with his Carolingian descent, could severely affect his position, eventually forced Wala to join a convent. ${ }^{31}$

The Carolingians tried to solve the problem of oversupply of those potentially willing to participate in power, which could have lead to its excessive fragmentation, not only through removing their natural sons from succession. Confining the dynastic circle, strivings made

${ }^{28}$ Cf. Brigitte Kasten, 'Chancen und Schicksale "unehelicher” Karolinger im 9. Jahrhundert', in Franz Fuchs and Peter Schmid (eds.), Kaiser Arnolf. Das ostfränkische Reich am Ende des 9. Jahrhunderts (Munich, 2002), 17-52.

${ }^{29}$ Kasten, Königssöhne, 165.

${ }^{30}$ Astronomus, Vita Hludowici imperatoris, ed. Ernst Tremp, MGH SS rer. Ger. in us. schol., lxiv (Hanover, 1995), chap. 21, p. 346; see Janet L. Nelson, 'Carolingian Royal Funerals', in Frans Theuws and eadem (eds.), Rituals of Power: From Late Antiquity to the Early Middle Ages (The Transformation of the Roman World, 8, Leiden, Boston and Cologne, 2000), 148; also, see Lorenz Weinrich, Wala. Graf, Mönch und Rebell. Die Biographie eines Karolingers (Historische Studien, 386, Lübeck, 1963), 28.

${ }^{31}$ Weinrich, Wala, $30 \mathrm{ff}$. 
to keep power in the hands of direct descendants, whilst eliminating the lateral lines, was the case with virtually every generation. Charles Martel's takeover implied not only the removal from power of his nephew Theudoald but also imprisonment of the sons of his other brother Drogo. ${ }^{32}$ There are rather firm indications of the fact that Pippin the Short's establishing himself as king in 751 was meant not only to reinforce the Carolingians' position against the old Merovingian dynasty but also, to no less extent, to unambiguously discern Pippin himself - by way of the anointment accompanying his royal elevation ${ }^{33}$ - from his next-of-kin: the younger stepbrother Grifo and, especially, his nephew Drogo with whom Pippin had theretofore had to share the office of mayor of the palace and the authority. In Pippin's concept, his move was meant to monopolise power in his hands while completely removing the other members of the Carolingian house from it. Soon after he came to the throne, the new king had Drogo closed in a cloister, and cracked down on Grifo who claimed his vested rights. ${ }^{34}$

The actions taken by Charles Martel or Pippin the Short, as well as by their successors Charlemagne or Louis the Pious, aiming at ensuring succession solely to their own sons and cutting distant relatives out of the picture, did not bring about a change in the Carolingian rulers' perception of the dynastic character of their authority. True, these actions led to a limited number of potential successors to the descendants of the ruling sovereign, depriving the remaining relatives of participation in the succession, but they essentially did not mean a rejection of the ideas of power - typical to the Carolingian tradition - as a sui generis common good of the entire dynasty; albeit restricted in each generation to the ruler's closest relatives, the rights to this good would be vested, on equal footing, to all the dynasty's

${ }^{32}$ Annales Mosellani, ed. Johann M. Lappenberg, MGH Scriptores, xvi (Hanover, 1859), 494; Annales Petaviani, ed. Georg H. Pertz, ibidem, i (Hanover, 1826), 7; see Semmler, 'Zur pippinidisch-karolingischen Sukzessionskrise', 25 ff.; Fouracre, The Age of Charles Martel, 74 ff.; cf. Joch, Legitimität und Integration, 102 ff.

33 See Arnold Angenendt, 'Pippins Königserhebung und Salbung', in Becher and Jarnut (eds.), Der Dynastiewechsel, 179-209; cf. Josef Semmler, Der Dynastiewechsel von 751 und die fränkische Königssalbung (Düsseldorf, 2003).

${ }^{34}$ Annales Petaviani, 11; Annales Mosellani, 495; Annales Mettenses priores, 43; see Matthias Becher, 'Drogo und die Königserhebung Pippins', Frühmittelalterliche Studien, xxiii (1989), 131-53; Michael J. Enright, Iona, Tara and Soissons: The Origin of the Royal Anointing Ritual (Berlin and New York, 1985), 107 ff.; cf. Kaschke, Die karolingischen Reichsteilungen, $89 \mathrm{ff}$. 
representatives. ${ }^{35}$ Having concentrated the power in his hands and cut his nephews out, Charles Martel decided in 741 to share the power among his legal sons. ${ }^{36}$ Similarly, Pippin the Short, who earlier removed his own nephews from power, provided the royalty he had seized to his both sons, Charlemagne and Carloman. ${ }^{37}$ As for Charlemagne, he took no different course. Once Carloman died in 771, he prevented the succession from being overtaken by Carloman's sons, and himself seized the power over the entire Frankish Kingdom, in view of successively hand over the reigns to his own offspring. ${ }^{38}$ Also, Louis the Pious, whilst omitting his nephew Bernard in his succession ordinance of 817 , granted the monarchal power rights to all his legitimate sons - Lothar, Pippin, and Louis of Germany. ${ }^{39}$ After his fourth lawful son Charles the Bald was born in 823, Louis took action that aimed at ensuring him too a share in the monarchal power and eventually, in 831, brought about a new division of the empire, in a way that took into account all of his sons. ${ }^{40}$

The conviction about the entitlements to participate in kingship, vested in the entire Carolingian family, determined to a significant extent the range of actions carried out in the following years, over almost the whole of the ninth century, by Louis's sons and grandsons.

${ }^{35}$ Cf. Franz-Reiner Erkens, 'Divisio legitima und unitas imperii. Teilungspraxis und Einheitsstreben bei der Thronfolge im Frankenreich', Deutsches Archiv für Erforschung des Mittelalters, lii (1996), 423-85.

${ }^{36}$ See fn. 19.

${ }^{37}$ Fredegar, Cont., chap. 53, pp. 192-3; Annales Mettenses priores, 55; see Classen, 'Karl der Große', 109 ff.; Rosamond McKitterick, Charlemagne: The Formation of a European Identity (Cambridge, 2008), 75 ff.; cf. Gunther G. Wolf, 'Die Königssöhne Karl und Karlmann und ihr Thronfolgerecht nach Pippins Königserhebung 750/51', Zeitschrift der Savigny-Stiftung für Rechtsgeschichte, Germanistische Abteilung, cviii (1991), 282-96.

${ }^{38}$ Annales regni Francorum, 32; see McKitterick, Charlemagne, 88 ff.

${ }^{39}$ Ordinatio imperii, ed. Alfred Boretius, MGH CrF, i, no. 136, pp. 270-3; see Kasten, Königssöhne, 165 ff.; Kaschke, Die karolingischen Reichsteilungen, 324 ff.

${ }^{40}$ Hludowici Pii capitularia, ed. Alfred Boretius and Viktor Krause, MGH CrF, ii (Hanover, 1897), no. 194 (Regni divisio), pp. 20-4. The decision issued by Louis only mentions three of his sons: Pippin, Louis and Charles, whilst Lothar, fallen out with him, is neglected; still, Lothar retained his authority over Italy, the area assigned to him beforehand; see Heinz Zatschek, 'Die Reichsteilungen unter Kaiser Ludwig dem Frommen. Studien zur Entstehung des ostfränkischen Reiches', Mitteilungen des Instituts für Österreichische Geschichtsforschung, xlix (1935), 185-224; Kaschke, Die karolingischen Reichsteilungen, $354 \mathrm{ff}$. 
Regardless of the disputes they waged against one another, and of their recurring attempts at removing their lateral relatives and limiting the dynastic circle to their own closest relatives, the idea of fraternal bonds linking them and shared responsibility of all the Carolingian dynasty members for the monarchy's fortunes remained valid and shaped, to a significant extent, the ideas about the throne succession principles. ${ }^{41}$ This was the way in which the relationships linking Louis the Pious's sons were to be settled by the Verdun arrangement of 843 , whereby they were granted equal rights to authority over the state left by their father who had died three years earlier. ${ }^{42}$ The Verdun settlements were complemented by the resolutions of the Synod of Yutz of 844 , which strongly emphasised a collective character of the monarchal authority exercised together by the Carolingian kings. ${ }^{43}$ The subsequent reunion of Louis the Pious's sons, in 847 at Meersen, confirmed this state of affairs and, in parallel formally recognised their own sons' rights to take over the royal rule in a future. ${ }^{44}$ In the conviction of the Carolingian dynasts, the kingship was to constitute

${ }^{41}$ See Reinhard Schneider, Brüdergemeine und Schwurfreundschaft. Der Auflösungsproze $\beta$ des Karlingerreiches im Spiegel der caritas-Terminologie in den Verträgen der karlingischen Teilkönige des 9. Jahrhunderts (Historische Studien, 388, Lübeck, 1964); Hans H. Anton, 'Zum politischen Konzept karolingischer Synoden und zur karolingischen Brüdergemeinschaft', Historisches Jahrbuch, xcix (1979), 55-132.

${ }^{42}$ Nithardi Historiarum libri IIII, ed. Ernst Müller, MGH SS rer. Germ. in us. schol., xliv (Hanover and Leipzig, 1907), chaps. 3-6, pp. 42-9; Annales Bertiniani, ed. Georg Waitz, MGH SS rer. Germ. in us. schol., v (Hanover, 1883), 29-30; Annales Fuldenses sive Annales regni Francorum orientalis, ed. Georg H. Pertz and Friedrich Kurze, MGH SS rer. Germ. in us. schol., vii (Hanover 1891), 34; see Heinrich Mitteis, 'Der Vertrag von Verdun im Rahmen der karolingischen Verfassungspolitik', in Theodor Mayer (ed.), Der Vertrag von Verdun. Neun Aufsätze zur Begründung der europäischen Völker- und Staatenwelt (Das Reich und Europa, 6, Leipzig, 1943), 66-100; François L. Ganshof, 'Zur Entstehungsgeschichte und Bedeutung des Vertrages von Verdun (843)', Deutsches Archiv für Erforschung des Mittelalters, xii (1956), 313-30; Peter Classen, 'Die Verträge von Verdun und von Coulaines 843 als politische Grundlagen des westfränkischen Reiches', Historische Zeitschrift, cxcvi (1963), 1-35.

43 Synodus ad Theodonis villam habita, ed. Alfred Boretius and Viktor Krause, MGH CrF, ii (Hanover, 1897), no. 227, pp. 112-16; see Anton, 'Zum politischen Konzept', 87 ff.

${ }^{44}$ Hlotharii, Hludovici et Karoli conventus apud Marsnam primus, ed. Alfred Boretius and Viktor Krause, MGH CrF, ii, no. 204, pp. 68-71; see Anton, 'Zum politischen Konzept', 106 ff.; Schneider, Brüdergemeine, 147 ff. 
a shared property of the entire house, with the rights to participate in it being vested, on equal footing, in all its representatives.

This being the case, it is no surprise that Henry I's decision to only provide the power to one of his sons, thus breaking with the Carolingian tradition, did not readily gain common acceptance in the East-Frankish Kingdom. The old concepts of the common right of all the members of the royal family to participate in the dynastic authority continued to be shared by a considerable part of the Reich's political elite, and referred to the new royal house as well. ${ }^{45}$ References to those concepts are clearly discernible in the historiographical works written in the second half of the tenth century, connected to a varying extent with the new dynasty. The idea of the common rule of all Henry I's sons, based upon fraternal love, was particularly strongly expressed - in a manner reminiscent of the rhetoric of the ninth-century 'brotherly' agreements between Carolingian rulers - in Hrotsvit of Gandersheim's Gesta Ottonis. The latter work mentions that after Henry's death, his three sons, albeit subject to Otto's suzerainty, co-ruled the kingdom left by their father. ${ }^{46}$ Yet, the resonance of the concepts highlighting the communal, dynastic character of the Liudolfings' rule re-echoed in Widukind of Corvey's story of Otto I's and his brother Henry's joint striving for increase the kingdom's territory, or in the remarks of Ruotger - biographer of Archbishop Bruno of Cologne, another Otto's brother - about the king's and Bruno's shared management of the state's affairs. ${ }^{47}$ It does not seem that we only deal with some historiographic constructions in this respect. As shown by the disputes waged, with varying intensity, over almost the entire Ottonian period, the conviction about the right vested in all the members of the royal family to participate in kingship essentially impressed its stigma, in a remarkable degree, on the Reich's political

${ }^{45}$ See Leyser, Rule and Conflict, 16-17, 86; Laudage, 'Hausrecht', 64 ff.; idem, “"Liudolfingisches Hausbewußtsein”. Zu den Hintergründen eines Kölner Hoftages von 965', in Hanna Vollrath and Stefan Weinfurter (eds.), Köln - Stadt und Bistum in Kirche und Reich des Mittelalters. Festschrift für Odilo Engels zum 65. Geburtstag (Cologne, 1993), 40 ff.

${ }^{46}$ Hrotsvithae opera III. 1: Gesta Ottonis, ed. Paul von Winterfeld, MGH SS rer. Germ. in us. schol., xxxiv (Berlin, 1902), 205, v. 25-32; cf. Jay T. Lees, 'Hrotsvit of Gandersheim and the Problem of Royal Succession in the East Frankish Kingdom', in Phyllis R. Brown, Linda A. McMillin, and Katharina M. Wilson, (eds.), Hrotsvit of Gandersheim: Context, Identities, Affinities, and Performances (Toronto, 2004), 13-28.

47 Widukind, ii. 36, p. 95; Ruotgeri Vita Brunonis, chap. 39, p. 39. 
realities - and, clashing against the new dynastic policy of the Ottonian rulers, exerted a major impact on the course of political occurrences.

In 938, Thankmar, Otto I's stepbrother and elder, born to Henry's first, subsequently dissolved, marriage with Hatheburg, stood up against Otto. ${ }^{48}$ In his account of those events, Widukind puts forward the central issue of the estate that in the past had been owned by Thankmar's mother: Otto's refusal to provide the estate to Thankmar apparently hustled the latter to rebel against the king. ${ }^{49}$ However, it does not seem that the dramatic dispute between the brothers, with the resultant death of Thankmar, may have actually boiled down solely to property-related questions. Widukind's not-quite-explicit report on the deputation sent by Thankmar to the Slavic barbarians seems to suggest that during Henry I's reign, his father might have entrusted him with important tasks related to the defence of the Reich's eastern frontier. ${ }^{50}$ There is no doubt, however, that his position was not the strongest. The succession ordinance of 929, providing that Otto was the only one to receive the throne, not only deprived Thankmar of the rights theretofore vested in the kings' sons, frustrating the hope to participate, in a future, in the royal authority: it also essentially called into question his membership in the ruling dynasty - as seemingly suggested by an entry in the Reichenau confraternity book where Thankmar's name did not appear alongside the names of royal family members but, instead, further down the list, among the Saxon aristocrats. ${ }^{51}$ In this context, special focus is deserved by the information on the circumstances of Thankmar's death, as provided by Widukind: Thankmar namely got killed in a church by the royal warriors that chased him as he sought refuge from them. As we learn from the chronicler's account, Thankmar, hiding in the temple, laid his weapons and gold necklace (torques) on the altar. ${ }^{52}$ The act of depositing the arms on the altar certainly symbolised Thankmar's decision to quit fighting and his readiness to surrender to his brother.

${ }^{48}$ Leyser, Rule and Conflict, 12 ff.; Glocker, Die Verwandten der Ottonen, 48 ff.; Laudage, 'Hausrecht', 59 ff.

49 Widukind, ii. 11 , p. 76.

${ }^{50}$ Ibidem, ii. 4, p. 70; see Schmid, 'Die Thronfolge', 149 ff.; Glocker, Die Verwandten der Ottonen, $46 \mathrm{ff}$.

${ }^{51}$ Das Verbrüderungsbuch der Abtei Reichenau, 63; see Schmid, 'Neue Quellen', $186 \mathrm{ff}$.

52 Widukind, ii. 11 , pp. 76-7. 
What kind of meanings could be related to the gold necklace being put off? Widukind's account is extremely sparing in this respect. It seems highly plausible, though, that the necklace worn by Thankmar is identifiable as a sign of his social position, a sort of insignia testifying to his membership in the royal lineage - challenged by some - and thus indicative of the rights, vested thereby in him, to wield a royal authority. ${ }^{53}$ Thankmar's reference to the torques takeoff gesture, along with the laying down of arms, as a token of his submission to Otto, seems to indicate that by standing up against his younger brother, he did not merely intend to sue his rights to his mother's property or, as Widukind elsewhere suggests, to take the office over from his recently deceased relative, margrave Siegfried. ${ }^{54}$ There was much more at stake: Otto was expected to recognise Thankmar's rights to participation in the monarchal power, ensuing from his affiliation with the royal dynasty.

We may only make guesses about Thankmar's aspirations to participate in Otto's kingship; as for Henry, the king's younger brother, there is no doubt at all that he long remained unable to come to terms with his having been removed from the succession, and made numerous attempts to acquire the royal crown. As may be inferred from Widukind, Otto had to take his ambitions into account from the very outset: the chronicler mentions that during Otto's coronation ceremony, Henry stayed in Saxony, offered for custody of margrave Siegfried, one of the new king's closest associates. ${ }^{55}$ Also, the account by Flodoard of Reims, recording a dispute arisen after Henry I's death between his sons, seems to imply that in spite of what had been settled in 929, the question whether Otto, the only and unquestionable successor of the deceased king, would take over the throne in 936, was not yet fully resolved. ${ }^{56}$

53 See Karl Hauck, 'Halsring und Ahnenstab als herrscherliche Würdezeichen', in Percy E. Schramm (ed.), Herrschaftszeichen und Staatssymbolik. Beiträge zu ihrer Geschichte vom dritten bis zum sechzehnten Jahrhundert, 3 vols. (MGH Schriften, 13/1, Stuttgart, 1954-78), i, 150-92; Ernst Karpf, Herrscherlegitimation und Reichsbegriff in der ottonischen Geschichtsschreibung des 10. Jahrhunderts (Historische Forschungen, 10, Stuttgart, 1985), 148-55; Laudage, 'Hausrecht', 59 ff.; Glocker, Die Verwandten der Ottonen, 48 ff.

54 Widukind, ii. 9, p. 73.

${ }^{55}$ Ibidem, ii. 2, p. 67.

${ }^{56}$ Les Annales de Flodoard, ed. Philippe Lauer (Paris, 1905), 64: "Heinrico rege sub isdem diebus obeunte, contentio de regno inter filios ipsius agitator; rerum tandem summa natu majori, nomine Othoni, obvenit." 
The fulfilment by Otto of the crowning ceremony did not however lead to quitting by Henry of his royal aspirations, nor did it mean that the dispute between the brothers came to an end. In the following years, Henry, supported by his mother, queen Mathilda, and by a significant number of the aristocrats, several times put forth his claims for participation in the monarchal rule, as justified by the old concepts of a dynastic nature of the royal suzerainty. Finally, in 948, Henry became reconciled with his brother and, quitting the design to win the royal crown, he satisfied himself with the half-kingly rank of duke of Bavaria, bestowed to him by Otto. ${ }^{57}$ The issue of rights to the throne, apparently vested in him due to his being a member of the royal family, was resumed by his son Henry the Quarrelsome. As he strove to acquire the kingship, he several times instigated, in the 970s, rebellions against his cousin Otto II. ${ }^{58}$ In 983, with Otto II's death, Henry did not limit himself to taking over the custody of the three-year-old son of the deceased emperor, then already anointed and crowed as king Otto III, but went as far as having declared himself a king by the aristocrats, the rulers of Bohemia and Poland as well as the Obodrites: Boleslav II, Mieszko I and Mstislav. ${ }^{59}$ Given the crown claims repeatedly posed by the Bavarian Liudolfings, it is no surprising that Otto II finally decided to resolve the problem of the

${ }^{57}$ Schmid, 'Die Thronfolge', 152 ff.; Leyser, Rule and Conflict, 12 ff.; Laudage, 'Hausrecht', 60 ff.; Glocker, Die Verwandten der Ottonen, 53 ff.; Althoff, Die Ottonen, 75 ff.; Matthias Becher, 'Loyalität oder Opposition? Die Sachsen und die Thronfolge im Ostfrankenreich (929-939)', in Caspar Ehlers, Jörg Jarnut, and Matthias Wemhoff (eds.), Deutsche Königspfalzen. Beiträge zu ihrer historischen und archäologischen Erforschung, vii: Zentren herrschaftlicher Repräsentation im Hochmittelalter. Geschichte, Architektur und Zeremoniell (Göttingen, 2007), 69-86.

${ }^{58}$ Glocker, Die Verwandten der Ottonen, 172 ff.; Althoff, Die Ottonen, 138 ff.

${ }^{59}$ Thietmari Merseburgensis episcopi Chronicon (hereafter: Thietmar), ed. Robert Holtzmann, MGH SS rer. Germ., N.S., ix (Berlin, 1935), iv. 2, p. 132; Annales Hildesheimenses, ed. Georg Waitz, MGH SS rer. Germ. in us. schol., viii (Hanover, 1878), 24; cf. Annales Quedlinburgenses, ed. Martina Giese, MGH SS rer. Germ. in us. schol., lxxii (Hanover, 2004), 470-1; Richeri Historiarum librii IIII, ed. Hartmut Hoffmann, MGH Scriptores, xxxviii (Hanover, 2000), iii. 97, p. 223; see Franz-Reiner Erkens, “ “... more Grecorum conregnantem instituere vultis?” Zur Legitimation der Regentschaft Heinrichs des Zänkers im Thronstreit von 984', Frühmittelalterliche Studien, xxvii (1993), 273-89; Althoff, Die Ottonen, 154 ff.; also, see Dominik Waßenhoven, 'Swaying Bishops and the Succession of Kings', in Lutger Körntgen and Dominik Waßenhoven (eds.), Patterns of Episcopal Power: Bishops in Tenth and Eleventh Century Western Europe (Berlin and Boston, 2011), 89-99. 
menace posed by them, in a way resembling the actions taken in the past by the Carolingian rulers against the lateral lines of the dynasty. After yet another rebellion of Henry the Quarrelsome was suppressed in 978, Otto did not show mercy to the defeated Bavarian duke who humbled himself before him, but instead sentenced him to timeless imprisonment under the custody of Bishop Folkmar of Utrecht. ${ }^{60}$ A vague mention of Henry the Quarrelsome's firstborn son - later emperor Henry II - being destined for the clergy and dispatched to Hildesheim makes legitimate the guess that what Otto II actually intended in 978 was not only to remove Henry from the political scene for good, but also to bring about a complete elimination from the political life of the entire Bavarian branch of the dynasty. ${ }^{61}$

Henry I's decisions made in 929 with respect to throne succession ensued, to a large extent, from the specific circumstances in which he happened to wield power. Elevated to the throne by the dukes, and forced to strictly cooperate with them, he was not in a position - even though he would have so desired - to refer to the rule exercise methods applied by his Carolingian predecessors. The dukes whose consent made it possible for Henry to come to the throne in 919 were disposed to accept the successor he would appoint but would instead have found it much harder to come to terms with the idea that Henry's entire family, a menace to their own position, could be distinguished in the Carolingian way. ${ }^{62}$

It is worth noting, though, that the changes taking place during Otto I's reign in the character of the relationships between the king and the dukes, leading to the latter being more strictly subjugated to the royal suzerainty, were not related to a resumption of the Carolingian succession tradition. ${ }^{63}$ Otto remained loyal in this respect to the solutions adopted by his father. What is more, departure from the Carolingian dynastic ideas is observable in the tenth century not

${ }^{60}$ Annales Hildesheimenses, 23; Gerhardi Vita S. Oudalrici episcopi Augustani, ed. Georg Waitz, MGH Scriptores, iv (Hanover, 1841), 417; Thietmar, iii. 7, p. 104; iv. 1, pp. 130-2.

${ }^{61}$ Fundatio ecclesiae Hildensemensis, ed. Adolf Hofmeister, MGH Scriptores, xxx, 2 (Leipzig, 1934), 945; see Stefan Weinfurter, Heinrich II. (1002-1024). Herrscher am Ende der Zeiten (Regensburg, 2002), 25-6; Althoff, Die Ottonen, 141.

${ }^{62}$ Cf. Althoff, Die Ottonen, 56 ff.; Zotz, 'Wie der Typ', 101 ff.

${ }^{63}$ See Gerd Althoff and Hagen Keller, Heinrich I. und Otto der Grosse. Neubeginn auf karolingischem Erbe (Persönlichkeit und Geschichte, Göttingen and Zurich, 1985). 
only in the East-Frankish Kingdom: similar developments occurred in a majority of territorial dominions which took shape beginning with the late ninth and early tenth century in the former Carolingian Empire area. The new dynasties striving for power - whether they assumed the royal title, as was the case with e.g. Burgundy ${ }^{64}$ or satisfied themselves with the old 'official' ranks, as with the West-Frankish dukes ${ }^{65}$ - were building their regal position upon the new succession principles, creating narrow vertically-oriented dynastic structures. Finally, in mid-tenth century, the new solutions were brought into effect also by the last Carolingian rulers of the West-Frankish Kingdom who eventually quit the old practice of handing over the crown to all their sons. In 954, after Louis IV d'Outremer died, only his eldest son Lothar was enthroned; Charles, the younger one, was thus ignored. ${ }^{66}$ Lothar, on his part, ignoring Charles's recurring claims for participation in the kingship, crowned - in 979, when he was still alive - his eldest son Louis $\mathrm{V}$ as king, possibly following the Ottonian pattern, and thence disregarding his younger, Otto, who was destined for the clergy ${ }^{67}$ As they strove to reinforce the very-recently-acquired

${ }^{64}$ See Eduard Hlawitschka, 'Zum Werden der Unteilbarkeit des mittelalterlichen Deutschen Reiches', in idem, Stirps regia. Forschungen zu Königtum und Führungsschichten im früheren Mittelalter. Ausgewählte Aufsätze. Festgabe zum seinem 60. Geburtstag (Frankfurt am Main, 1988), 255.

${ }^{65}$ See Andrew W. Lewis, 'Anticipatory Association of the Heir in Early Capetian France', American Historical Review, lxxxiii, 4 (1978), 906-27; Jane Martindale, 'Succession and Politics in the Romance-Speaking World, c. 1000-1140', in Michael Jones and Malcolm Vale (eds.), England and her Neighbours, 1066-1453: Essays in Honour of Pierre Chaplais (London and Ronceverte, W. Virg., 1989), 19-41; George Garnett, 'Ducal Succession in Early Normandy', in George Garnett and John Hudson (eds.), Law and Government in Medieval England and Normandy: Essays in Honour of Sir James Holt (Cambridge, 1994), 80-110. Similar strivings to ensure the throne for only one of the sons are simultaneously encountered in the duchies of Lorraine and Bavaria; see Hlawitschka, 'Zum Werden', 256.

${ }^{66}$ Shortly before his death, Louis himself could have possibly made an attempt - in line with the old Carolingian tradition - to promote to kingship and to ensure the throne of Burgundy to Charles; see Carlrichard Brühl, 'Karolingische Miszellen', Deutsches Archiv für Erforschung des Mittelalters, xliv (1988), 385 ff.

${ }^{67}$ Richeri Historiarum librii IIII, iii. 91, p. 220; see Ferdinand Lot, Les derniers Carolingiens: Lothaire, Louis V, Charles de Lorraine (954-991) (Paris, 1891), 108-9; Kasten, Königssöhne, 492 ff.; Giese, 'Die designativen Nachfolgeregelungen', 492 ff.; Geoffrey Koziol, 'A Father, His Son, Memory, and Hope: The Joint Diploma of Lothar and Louis V (Pentecost Monday, 979)', in Jürgen Martschukat and Steffen 
power and to transform it into a hereditary one, the first Capetian kings resolved to resort to similar measures. In 987, Hugh Capet was allowed by the aristocrats to have his son Robert the Pious crowned. ${ }^{68}$ As for Robert, he first contrived the crowning of his eldest son Hugh, in 1017, and subsequently, following Hugh's unexpected death in 1025, ordered that his other son Henry I be crowned. ${ }^{69}$ Resulting from those actions, the custom of having a new ruler crowned while his predecessor was still alive became part of the French Kingdom's political practice, contributing to a significant extent to the solidification of the related succession model whereby the authority would only be handed over to one of the king's sons. ${ }^{70}$

It is not an easy task to find the unambiguous reasons for those changes, taking place in the tenth century in the post-Carolingian European territory, in the ways the dynastic identity was shaped and dynastic relations built. There were possibly many factors behind that. Certainly of importance for the reinforcement of the new dynastic model and of the related new throne succession rules were the concepts of kingship emphasising its sacred bases, which were reintensified in that period mainly in the Reich, but not only there. According to these concepts, monarchal authority was primarily seen as a religious mission, a ministerium assumed by the ruler through the act of royal anointing. ${ }^{71}$ The image of king thus created - the

Patzold (eds.), Geschichtswissenschaft und 'performative turn'. Ritual, Inszenierung, Performanz vom Mittelalter bis zur Neuzeit (Norm und Struktur, 19, Cologne etc., 2003), 83-103; Geoffrey Koziol, The Politics of Memory and Identity in Carolingian Royal Diplomas: The West Frankish Kingdom (840-987) (Turnhout, 2012), 548 ff.; Joachim Ott, Krone und Krönung. Die Verheißung und Verleihung von Kronen in der Kunst von der Spätantike bis um 1200 und die geistige Auslegung der Krone (Mainz, 1998), $104 \mathrm{ff}$.

${ }^{68}$ Richeri Historiarum librii IIII, iv. 12-13, pp. 239-41.

${ }^{69}$ Rodulfi Glabri Historiarum libri quinque, ed. and trans. John France (Oxford, 1989), iii. 32, pp. 150-2, iii. 34, p. 156.

${ }^{70}$ See Andrew W. Lewis, Royal Succession in Capetian France: Studies on Familial Order and the State (Cambridge, MA and London, 1981).

${ }^{71}$ See, e.g., Stefan Weinfurter, 'Idee und Funktion des "Sakralkönigtums" bei den ottonischen und salischen Herrschern (10. und 11. Jahrhundert)', in Rolf Gundlach and Hermann Weber (eds.), Legitimation und Funktion des Herrschers. Vom ägyptischen Pharao zum neuzeitlichen Diktator (Schriften der Mainzer Philosophischen Fakultätsgesellschaft, 13, Stuttgart, 1992), 99-127; Stefan Weinfurter, 'Zur "Funktion” des ottonischen und salischen Königtums', in Michael Borgolte (ed.), Mittelalterforschung nach der Wende (Historische Zeitschrift. Beiheft NF, 20, Munich, 
God's anointed, called by God to govern on His behalf and to His likeness - left not much room for the ideas of a collective nature of the monarchal suzerainty, one which would be equally vested in all the members of the ruling family. ${ }^{72}$ The dissemination of the custom of

1995), 249-361; Ludger Körntgen, Königsherrschaft und Gottes Gnade. Zu Kontext und Funktion sakraler Vorstellungen in Historiographie und Bildzeugnissen der ottonisch-frühsalischen Zeit (Berlin, 2001); Egon Boshof, 'Die Vorstellung vom sakralen Königtum in karolingisch-ottonischer Zeit', in Franz-Reiner Erkens (ed.), Das frühmittelalterliche Königtum. Ideelle und religiöse Grundlagen (Berlin and New York, 2005), 331-58; Franz-Reiner Erkens, Herrschersakralität im Mittelalter. Von den Anfängen bis zum Investiturstreit (Stuttgart, 2006), 157 ff.

72 Cf. Laudage, “Liudolfingisches Hausbewußtsein”, $56 \mathrm{ff}$. It is worth noting, however, that in the case of the Carolingians, their shared conviction of the essentially religious nature of kingship exerted only a slight impact on the succession practice, and did not result in a severance of the 'corporative' vision of monarchal authority as a shared property of the whole dynasty. Charlemagne's ordinance of 806 , so-called Divisio regnorum, regarding the throne succession rules, may be interpreted as an intent to diversify the monarchal rights vested in his sons, which manifested itself in privileging the oldest of them, Charles, who might have been seen as a potential holder of emperorship, and in the introduction within the individual provincial kingdoms of the rule whereby succession of the throne was only assumed by one of the sons of the previous ruler. Nevertheless, Divisio regnorum assumed joint responsibility of all the sons for defence of the empire and custody over the Roman Church; cf. Divisio regnorum, 126-30; see Classen, 'Karl der Große', 109-34; Kasten, Königssöhne, 138 ff.; Johannes Fried, 'Erfahrung und Ordnung. Die Friedenskonstitution Karls des Großen vom Jahr 806', in Brigitte Kasten (ed.), Herrscher- und Fürstentestamente im westeuropäischen Mittelalter (Norm und Struktur, 29, Cologne etc., 2008), 145-92; Giese, 'Die designativen Nachfolgeregelungen', 453 ff.; cf. Dieter Hägermann, 'Reichseinheit und Reichsteilung. Bemerkungen zur Divisio regnorum von 806 und zur Ordinatio imperii von 817', Historisches Jahrbuch, xcv (1975), 278-307; Kaschke, Die karolingischen Reichsteilungen, 298 ff.; idem, 'Tradition und Adaption. Die Divisio regnorum und die fränkische Herrschaftsnachfolge', in Kasten (ed.), Herrscher- und Fürstentestamente, 259-90; also, see Carl I. Hammer, 'Christmas Day 800: Charles the Younger, Alcuin and the Frankish Royal Succession', English Historical Review, cxxvii (524) (2012), 1-23. The idea of sacred nature of kingship impressed a much more distinct stamp on the succession decisions of Louis the Pious, contained in his Ordinatio imperii of 817 , whereby the intention to preserve the state's unity, to make Lothar, Louis's eldest son, co-emperor, and to subjugate to his power the other brothers, who were equipped with peripheral provinces, had an unambiguously religious rationale behind it; cf. Ordinatio imperii, 270-3. However, the succession design presented in Ordinatio eventually remained undelivered, as is known; taking up the issue of throne succession in the later years, Louis referred again to the traditional ideas of a communal character of the Carolingian kingship; see Egon Boshof, 'Einheitsidee 
handing over the throne exclusively to one of the sons of the governing ruler was doubtless fostered also by the strengthening tendencies to perceive a political community, or state, in a more abstract manner, highlighting the entity's integrity and subjectivity in its relationships with its ruling monarch. ${ }^{73}$ One may as well ponder to what extent the emergence of new hierarchised dynastic families was possibly associated with the concurrent fundamental transformations in the awareness, and thus also the organisational forms, of the familial structure of the former Carolingian Empire's aristocracy. Resulting from those changes, the blood relationships: extensive, amorphic, liable to incessant transformations, extending to both agnatic and cognatic relatives - the relationships that earlier on determined the aristocrats' identity - now tended to be replaced by new, much more

und Teilungsprinzip in der Regierungszeit Ludwigs des Frommen', in Peter Godman and Roger Collins (eds.), Charlemagne's Heir: New Perspectives on the Reign of Louis the Pious (814-840) (Oxford, 1990), 161-89; Kasten, Königssöhne, 165 ff.; Steffen Patzold, 'Eine "loyale Palastrebellion" der "Reichseinheitspartei”? Zur Divisio imperii von 817 und zu den Ursachen des Aufstands gegen Ludwig den Frommen im Jahre 830', Frühmittelalterliche Studien, xl (2006), 43-77; Kaschke, Die karolingischen Reichsteilungen, $324 \mathrm{ff}$. Still, one might consider to what extent the actions taken by Charles the Bald, meant to remove his younger sons from succession and enabling, as a final result, his eldest son Louis the Stammerer to take over the throne on his own, could have been informed by the concepts of sacred nature of kingship, elaborated in Charles's environment - particularly, the reinstated significance of the royal anointment ceremony in the West-Frankish Kingdom in mid-ninth century, as a ritual devised for introducing the ruler into the monarchal rights. There is a strong case that also Louis the Stammerer intended in 879, shortly before his death, to pass over the throne to his eldest son Louis III. Resulting from the agreement between the competing groups of magnates, it was resolved that the authority be provided to both sons of the deceased king - that is, Louis and his younger brother Carloman; see Kasten, Königssöhne, 428 ff.; Giese, 'Die designativen Nachfolgeregelungen', 483 ff.

${ }^{73}$ Cf. Gerd Tellenbach, 'Die Unteilbarkeit des Reiches. Ein Beitrag zur Entstehungsgeschichte Deutschlands und Frankreichs', Historische Zeitschrift, clxiii (1941), 20-42; Helmut Beumann, 'Zur Entwicklung transpersonaler Staatsvorstellungen', in Theodor Mayer (ed.), Das Königtum. Seine geistigen und rechtlichen Grundlagen. Mainau-Vorträge 1954 (Vorträge und Forschungen, 3, Lindau and Constance, 1956), 185-224; Karl Schmid, 'Das Problem der "Unteilbarkeit des Reiches"', in idem (ed.), Reich und Kirche vor dem Investiturstreit. Vorträge beim wissenschaftlichen Kolloquium aus Anlaß des achtzigsten Geburtstags von Gerd Tellenbach (Sigmaringen, 1985), 1-15; Hlawitschka, 'Zum Werden', 247-68; Franz-Reiner Erkens, 'Einheit und Unteilbarkeit. Bemerkungen zu einem vielerörterten Problem der frühmittelalterlichen Geschichte', Archiv für Kulturgeschichte, lxxx (1998), 269-95. 
enduring lineages, based on strict patrilineal and agnatic bonds. ${ }^{74}$ Regardless, however, of the reasons that led to the emergence of a new, dynastic familial organisation model - let us name it Ottonian in the post-Carolingian Europe, there is no doubt that, beginning with the tenth century, it started setting - though not without resistance, as the conflicts seen in the Reich testified - the basic point of reference for the shaping of the familial, or ancestral, identity and building of family ties, among the ruling houses as well as aristocratic families.

In what ways those changes in the shaping of the familial identity and family ties, taking place in post-Carolingian Europe, exerted, or at least could exert, an impact on the ways the ruling family and its place in the authority structures of the new polities emerging in the ninth and tenth centuries in the area's peripheries were perceived, is hard to clearly state. While leaving this issue unresolved, it seems that the changes in question may offer a good point of reference, allowing for placing in an appropriate context the processes and phenomena occurring outside the frontiers of the former Carolingian Empire.

Essentially, given the scarcity of sources, our knowledge on the strategies applied by the dynasties ruling the new polities in building their own positions and shaping political relations with respect to their members and the communities subordinated to their authority, is much limited. The old concepts of lineage-based system and patrimonial state offer ostensible solutions, as a matter of fact, and essentially becloud the picture ${ }^{75}$ Referring to the succession law principles when it comes to explaining the rules governing the order of succession to the throne leads one to move around in the sphere of abstract legal

${ }^{74}$ Karl Schmid, 'Zur Problematik von Familie, Sippe und Geschlecht. Haus und Dynastie beim mittelalterlichen Adel. Vorfragen zum Thema "Adel und Herrschaft im Mittelalter"', Zeitschrift für die Geschichte des Oberrheins, cv (1957), 1-62; Georges Duby, 'Lignage, noblesse et chevalerie au XIIe siècle dans la région mâconnaise. Une révision', Annales ESC, xxvii (1972), 803-24; Régine Le Jan, Famille et pouvoir dans le monde franc (VIIe-Xe siècle). Essai d'anthropologie sociale (Paris, 1995); Werner Hechberger, Adel im fränkisch-deutschen Mittelalter. Zur Anatomie eines Forschungsproblems (Mittelalter-Forschungen, 17, Ostfildern, 2005), 306 ff.; cf. Constance Brittain Bouchard, 'Those of My Blood': Constructing Noble Families in Medieval France (Philadelphia, 2001).

${ }^{75}$ Cf. Jacek Matuszewski, 'Polska monarchia patrymonialna - opis rzeczywistości czy produkt dziewiętnastowiecznej historiografii?', in Andrzej Marzec and Maciej Wilamowski (eds.), Król w Polsce XIV i XV wieku (Maiestas, Potestas, Communitas, 1, Cracow, 2006), 137-53. 
concepts, often poorly testified by the sources and proving distant from the real mechanisms of functioning of the political life - as shown by the studies on the Carolingian successions, for that matter. ${ }^{76}$ It tends to be all too often neglected that the ruling houses - similarly to the aristocratic families - ought to be perceived not just as (or, not only as) blood-ties-based communities but rather, as political constructs. Genealogical relations formed but an element of a compound system wherein a variety of political, ideological, or social factors and drivers were paramount, determining the identity of those families' members, and their internal structure. ${ }^{77}$ Whilst not drilling down into these issues in detail, let us evoke three examples of polities rooted in diverse traditions: Rus', Hungary, and Poland. We will now try to take a snapshot of the three dissimilar and, at the same time, similar ways in which the dynastic relations were shaped and dynastic identity built.

Let us begin with Rus'. The tradition recorded by The Tale of the Bygone Years (or The Russian Primary Chronicle, Повтость временныхь лгть), presenting the earliest history of the Kiev rulers, emphasises the dynastic nature of their authority, founded on the filial succession. True, there are the three brothers standing at the origins of the dynasty (as the account, made part of the history of the ruling family most probably in 1030s, tells us), the subsequent story only refers to the offspring of one of them, Rurik. ${ }^{78}$ The figure of Oleg distorts this picture, to an extent: ${ }^{79}$ the Primary Chronicle namely

${ }^{76}$ See Matthias Becher, 'Vater, Sohn und Enkel. Die Bedeutung von Eintrittsund Anwachsungsrecht für die Herrschaftsnachfolge im Frankenreich', in Kasten (ed.), Herrscher- und Fürstentestamente, 301-19.

${ }^{77}$ Cf. Ian N. Wood, 'Deconstructing the Merovingian family', in Richard Corradini, Max Diesenberger and Helmut Reimitz (eds.), The Construction of Communities in the Early Middle Ages: Texts, Resources and Artefacts (Transformation of the Roman World, 12) (Leiden and Boston, 2003), 149-71.

${ }^{78}$ Povest' vremennykh let, ed. Dmitrii S. Likhachëv, i (Moscow, 1950), 18; see Elena A. Mel'nikova, 'Ryurik, Sineus i Truvor v drevnerusskoĭ istoriograficheskoĭ traditsii', in Tat'yana M. Kalinina (ed.), Pamyati chlena-korrespondenta RAN Anatoliya Petrovicha Novosel'tseva (Drevnersshie gosudarstva Vostochnoĭ Evropy [hereafter: DgVE]. 1998, Moscow, 2000), 143-59; eadem, 'Ryurik i vozniknovenie vostochnoslavyanskoĭ gosudarstvennosti v predstavleniyach drevnerusskikh letopistsev XI - nachala XII v.', in Mikhail B. Bibikov, eadem, and Vladislav D. Nazarov (eds.), Ryurikovichi $i$ rossiǔskaya gosudarstvennost' (DgVE. 2005, Moscow, 2008), 47-75.

${ }^{79}$ See Elena A. Mel'nikova, 'Pervye russkie knyaz'ya: o printsipakh rekonstruktsii letopistsem ranneĭ istorii Rusi', Vostochnaya Evropa $v$ drevnosti $i$ srednevekov'e (hereafter: VEds), xiv (2002): Mnimye real'nosti v antichnoĭ $i$ srednevekovoŭ istoriografii, 150. 
tells us he descended from Rurik's family, but does not make their kinship explicit. After Rurik's death, Oleg, following the will of the deceased ruler, took over the governance together with custody over his son Igor. ${ }^{80}$ It was only after Oleg's death that Igor was to come to power. ${ }^{81}$ The earliest history of the kin ruling Rus' has been differently described by the Novgorod First Chronicle, whereby the princely authority was handed over, since the very beginning, within Rurik's family, as an uninterrupted chain of filial successions: Igor took the rule over directly from his father, whilst Oleg, whose blood relationship with the princely dynasty is not even mentioned, acted at his side merely as a voivode. ${ }^{82}$ The picture is further complicated by texts, incorporated in the Primary Chronicle, of the Byzantine treaties concluded in 912 by Oleg and in 944 by Igor, which, beside the grand prince - i.e. Oleg and Igor, respectively - mention a number of other princes who supposedly were related to them by blood. ${ }^{83}$ Igor's treaty describes this kinship in more detail for two individuals it mentions, Igor and Akun (Hakon): both are named the нети Игоревъ. ${ }^{84}$ The meaning of нети is not completely clear; the term nepos seems closest to it, though. ${ }^{85}$ Still, it is hard to resolve whether they were related to Igor by agnatic or matrilineal consanguinity. Rus' prince 'HLGW' (Helge - Oleg), mentioned in a Khazar document dating probably to the 940s and kept in Cambridge, also tends to be associated with the Kiev-ruling dynasty: he first fought against the Khazars and later on, in the forties, led an expedition against Byzantium. ${ }^{86}$ The conviction whereby the

${ }^{80}$ Povest' vremennykh let, 19.

${ }^{81}$ Ibidem, 31.

${ }^{82}$ Novgorodskaya pervaya letopis' starshego i mladshego izvoda, ed. Arseniǔ N. Nasonov (Moscow and Leningrad, 1950), 107.

${ }^{83}$ Povest' vremennykh let, 25-6, 34-5; see Aleksandr V. Nazarenko, 'Nekotorye soobrazheniya o dogovore Rusi s grekami $944 \mathrm{~g}$. v svyazi s politicheskol strukturoĭ Drevnerusskogo gosudarstva', VEds, viii (1996): Politicheskaya struktura Drevnerusskogo gosudarstva, 58-63.

${ }^{84}$ Povest' vremennych let, 34.

${ }^{85}$ See Izmail I. Sreznevskij, Materialy dlya slovarya drevne-russkago yazyka po pis'mennym' pamjatnikam', 3 vols. (Saint Petersburg, 1893-1912), ii, col. 433.

${ }^{86}$ See Constantine Zuckerman, 'On the Date of the Khazars' Conversion to Judaism and the Chronology of the Kings of the Rus Oleg and Igor: A Study of the Anonymous Khazar Letter from the Genizah of Cairo', Revue des études byzantines, liii (1995), 237-70; Vladimir J. Petrukhin, 'Knyaz' Oleg, Khelgu Kembridzhskogo dokumenta i russkiǔ knyazheskiǔ rod', in Kalinina (ed.), Pamyati, 222-9. 
rights to the rule over Kiev were vested in the tenth century not only in the princes known from the Primary Chronicle, who ceded the throne one to the other, father to son, in each subsequent generation, is reinforced by the fragments of Constantine VII Porphyrogenitus's De administrando imperio discussing the Rus' affairs. On the one hand, the Byzantine emperor mentions Igor there, naming him the 'archon' of Rus', along with his son Sviatoslav; on the other, he seems to indicate that the power over Rus' must have been shared by them with some other rulers. Further down the account, reference is made not to a single prince of Rus' but 'archons' are mentioned, in plural, who, together with the all the people of Rus', departed from Kiev in November and betook themselves to the pol'ud'e ( $\pi \circ \lambda \dot{v} \delta l \alpha$, rounds) to collect the tribute from their subjugated Slavonic peoples. ${ }^{87}$ As a result, it may be inferred - contrary to the tradition recorded in the Primary Chronicle - that the structure of the family who ruled Kiev was more complex, and that it ought to be seen, contrary to the chronicle's story, not as a vertically-oriented dynasty but as a wider blood-related group. Members of this clan, as the group has usually been referred to, were related based on various blood ties, not limited perhaps to agnates, and wielded authority on a shared basis. ${ }^{88}$ The Primary Chronicle narrative mentions none of those princes, though. By all indications, somewhere in the middle of the tenth century, Igor's direct descendants managed to monopolise the power in their hands. ${ }^{89}$ In any case, setting off in 970 on his expedition to the Balkans, Sviatoslav could only divide his subject dominion between

${ }^{87}$ Constantine Porphyrogenitus, De administrando imperio, ed. Gyula Moravcsik, trans. Romilly J. H. Jenkins (Corpus Fontium Historiae Byzantinae, 1, Washington, 1967), chap. 9, pp. 56-63; see Aleksandr V. Nazarenko, 'H E $\Xi \Omega$ P $\Omega \Sigma I A$ : k politicheskoì geografii Drevnerusskogo gosudarstva serediny X veka', in Tat'yana N. Dzhakson, Irina G. Konovalova, and Gocha P. Tsetskhladze (eds.), Gaudeamus igitur. Sbornik stateĭ k 60-letiyu A. V. Podosinova (Moscow, 2010), 294-301.

${ }^{88}$ Aleksandr V. Nazarenko, "Sly i gostie": o strukture politicheskoĭ elity Drevneĭ Rusi v pervoĭ polovinie - seredine X veka', VEds, xix (2007): Politicheskie instytuty $i$ verkhovnaya vlast' (Moscow, 2007), 169-75; Wladyslaw Duczko, Viking Rus: Studies on the Presence of Scandinavians in Eastern Europe (Leiden, 2004), 210 ff.; also, see Mikhail B. Sverdlov, Domongol'skaya Rus': Knyaz' $i$ knyazheskaya vlast' na Rusi VI - pervol̆ treti XIII v. (Saint Petersburg, 2003), 148 ff.

${ }^{89}$ Cf. Aleksandr V. Nazarenko, 'Dinasticheskiĭ stroı̆ Ryurikovicheĭ X-XII vekov v sravnitel'no-istoricheskom osveshchenii', in idem, Drevnyaya Rus' i slavyane (DgVE. 2007, Moscow, 2009), 55. 
his three sons - Iaropolk, Oleg, and Vladimir..$^{90}$ None of the remaining Kiev 'archons' Constantine Porphyrogenitus was aware of could possibly participate in the authority that was appurtenant solely to the lineage of Igor/Sviatoslav. The fights that broke out in Rus' soon after Sviatoslav died in 972 were only joined by his sons, who proved responsible, on an exclusive basis, for the resolution of the succession issue and the rights to superior authority over the entire Kiev state. ${ }^{91}$ The course of this process of closing up the princely family and consolidation of power by the Igor/Sviatoslav lineage cannot be traced down in much detail. What it resulted in was, however, not only that distant relatives were eventually deprived of power but also pushed outside the frame of a dynastic tradition. ${ }^{92}$

Another attempt at internal reconstruction of this new dynastic structure, limited to Igor's and Sviatoslav's offspring, is apparently testified for the early eleventh century. This is how Vladimir the Great's actions aiming at handing over the throne of Kiev to Boris, one of his sons, can be interpreted. ${ }^{93}$ Taken supportively against their father, the action of Vladimir's remaining sons ruling the peripheral provinces entrusted by him to them, shows that the dispute was not merely about who of the brothers would be allocated the leading role in their state - governed by them on a shared, 'Carolingian-style' basis - but it extended to certain much more serious issues, related to the very essence of the dynasty's form and the place allocable (or not) within it for the sons cut off from the succession. By all indications, the takeover of the throne of Kiev by Boris was meant, according to Vladimir's design, not only to subjugate his other brothers to his power but to outright push them out of the circle of those entitled to share it. A new succession model was thus to be established, whereby the authority would be transferred, in each subsequent generation, from the father to one of his sons, leaving the remaining relatives of the ruler outside of the frame of the dynasty being thus created.

${ }^{90}$ Povest' vremennykh let, 49-50.

${ }^{91}$ Ibidem, 53-6; see Oleg M. Rapov, Knyazheskie vladeniya na Rusi v X-pervǒ polovine XIII v. (Moscow, 1977), 32 ff.; Sverdlov, Domongol'skaya Rus', 234 ff.

92 Cf. Alexandr Rukavishnikov, 'Tale of Bygone Years: the Russian Primary Chronicle as a family chronicle', Early Medieval Europe, xii, 1 (2003), 53-74.

93 See Andrzej Poppe, 'Spuścizna po Włodzimierzu Wielkim. Walka o tron kijowski 1015-1019', Kwartalnik Historyczny, cii, 3/4 (1995), 3-22. 
Vladimir's designs were not delivered, in the result. After his death in 1015, his other sons laid their own claims in view of taking over their paternal heritage and prevented Boris from succeeding to the throne. The scale of the conflict that flared up between Vladimir's sons and the drastic measures they applied against one another leave no doubt that the conviction about the rights to participate in power, vested equally in all the ruling family members, continued to determine - and crucially so - the character of the ideas associated with monarchal suzerainty and proved prevalent with respect to the course of political occurrences. In a situation that the monarchal aspirations of each of Vladimir's sons eager to take succession after their father were justifiable by the very fact that they belonged to the ruling lineage, the dispute could only be resolved through consent to share power, have the state divided, or having the competitor(s) physically eliminated. ${ }^{94}$

The dynastic plans Vladimir did not manage to deliver were taken up anew in mid-eleventh century, in a modified fashion, by Iaroslav the Wise, a son of Vladimir. While it is not completely clear whether the prince's purpose was exactly this, the so-called succession act he published in 1054 resultantly caused a factual limitation of those authorised to exercise the power over Kiev, or even the entire land of Rus', to the offspring of his three selected sons: Iziaslav, Sviatoslav, and Vsevolod. The other sons and their offspring, similarly as the members of another branch of the family, descending from Iaroslav's brother named Iziaslav, whose rights to power he had earlier managed to establish for Polotsk only, had thence to satisfy themselves with the peripheral provinces allotted to them. While retaining their princely status and continually perceived as, on the whole, members of the ruling family, they were refused the right to rule Kiev. This was to be assigned, on exclusive basis, to three distinguished lines of the dynasty. ${ }^{95}$ This state of affairs, which took shape in the course of the disputes carried on in the latter half of the eleventh century by the Rurikids, was formally confirmed in 1097, by means of the resolutions made in Liubech. The princes gathered at the convention

94 See Sverdlov, Domongol'skaya Rus', $318 \mathrm{ff}$.

${ }^{95}$ See Aleksandr V. Nazarenko, 'Drevnerusskoe dinasticheskoe stareǐshinstvo po "ryadu” Yaroslava Mudrogo i ego tipologicheskie paralleli - real'nye i mnimye', in idem, Drevnyaya Rus', 7-28; idem, “"Ryad” Jaroslava Mudrogo v svete evropeǐskoĭ tipologii', in ibidem, 29-46. 
determined the range of the dominions to be owned by the specified lines of the dynasty, stipulating the rights to the principalities within the land of Rus' and, consequently, to the authority of Kiev, solely for the descendants of the aforesaid three sons of Iaroslav the Wise. ${ }^{96}$ The arrangement of relations linking the individual members of the Rurikid dynasty, shaped in the latter half of the eleventh century, by no means meant a breakaway from the until-then-existing ideas of a collective, or corporative, character of the princely authority which formed a shared property of the entire princely house. If anything, these ideas were narrowed down, in a peculiar way, to its individual branches and their subject territories. The belief that princely authority ought to be vested, on equal footing, within the dominion being its property, to all the members of the singled-out line of the governing kin, remained the point of reference for the actions taken by the Rus' princes. ${ }^{97}$

As Constantine Porphyrogenitus makes it apparent, also in case of the Arpad dynasty, ruling Hungary, there was an extensive bloodrelated group, aware of the genealogical ties existing between its members, and of the rights to participate in power based thereupon. The Byzantine emperor's account, itself based on the information provided by one of the Hungarian dynasts on his visit to Constantinople as an envoy, evokes an image of a four-generation, multiplied ruling family, encompassing five sons, five grandsons and one greatgrandson of the first (as Constantine has it) Hungarian ruler, 'archon' Árpád, son of Álmos. ${ }^{98}$ Constantine's description strongly highlights that the only entitled to the superior authority over the Hungarians were Árpád's family members who exercise their power in a sequence. The author being referred to offers no detailed description of the throne succession, though; ${ }^{99}$ neither does he name the rulers succeeding Árpád. Instead, he presents an extensive genealogy of his descendants, specifying a total of eleven individuals. The emperor

${ }^{96}$ Povest' vremennykh let, 170-1.

${ }^{97}$ See Nazarenko, 'Dinasticheskiǔ stroŭ', 47-87; also, see Sverdlov, Domongol'skaya Rus', 475 ff.; Alekseĭ P. Tolochko, Knyaz' v Drevneı Rusi: Vlast', sobstvennost', ideologia (Kiev, 1992), 35ff., 67 ff.

98 On presenting the Arpads' genealogy, Constantine only enumerates Árpád's four sons; see Constantine Porphyrogenitus, De administrando, chap. 40, p. 179; yet, he mentions one more of them earlier in the same chapter; see ibidem, p. 176 .

${ }^{99}$ Ibidem. 
indeed remarks that Phalitzis, one of Árpád's grandsons, acted as the 'archon' at that time, but neither he nor his background dynastic line was distinguished in some peculiar way. Both Phalitzis and his father are enumerated in a sequence, along with the other sons and grandsons of Árpád. The impression one infers is that, on taking down his account, Constantine attached greater attention to presenting members of Árpád's kin, remarking who of them were dead and who was still alive, and to determining the character of their mutual kinship bonds, rather than indicating the ruler reigning at his own time or those before him on the throne.

It may be presumed, with high degree of certainty, that the emphases identifiable in the Constantine's record reflect, to an essential extent, the manner in which the relations amongst the Hungarians had been reported to him by his Hungarian guest Termazous, Árpád's grandson. What kind of purpose actually motivated the Arpad dynast's mission remains not completely clear. As a result, it is not certain whether Termazous and another Hungarian ruler who accompanied him - the military leader Bulscú, who in 955 was hanged on order of Otto I, following the battle of Lechfeld ${ }^{100}$ - represented in Constantinople, primarily, the interests of 'archon' Phalitzis, or perhaps their own ones, as they strove for developing an independent relationship with Byzantium. ${ }^{101}$ Regardless, however, of any doubts in this respect, the place allocated in Constantine's argument to the genealogy of the Arpads, which in all probability follows what Termazous made him aware of, is sufficiently strong evidence that the point of reference for the authority concepts they shared, as their subject community probably also did, was the conviction whereby the authority was, in the first place, property of the entire family - taken broadly, encompassing Ârpád's whole offspring, and

100 Annales Sangallenses maiores, dicti Hepidanni, ed. Ildefons von Arx, MGH Scriptores, i (Hanover, 1826), 79: "Otto rex cum Agarenis pugnabat in festivitate sancti Laurentii, eosque Deo auxiliante devicit. Et erat numerus eorum 100 milia et multi illorum comprehensi sunt cum rege eorum nomine Pulszi, et suspensi sunt in patibulis."

${ }^{101}$ Cf. Laszlo Varady, 'Revision des Ungarn-Image von Konstantinos Porphyrogennetos. Textanalysen und Reinterpration zu den Aussagen des Konstantinos Porphyrogennetos über die Politikgeschichte der Ungarn', Byzantinische Zeitschrift, lxxxii (1989), 22-58; Alexandru Madgearu, 'The Mission of Hierotheos: Location and Significance', Byzantinoslavica, lxvi (2008), 119-38. 
thereafter his individual representatives, exercising the supreme rule in a one-after-another sequence. ${ }^{102}$

Yet, the Arpads' dynastic tradition as reported by the anonymous Gesta Hungarorum, compiled probably in the early thirteenth century, ${ }^{103}$ offers us a different picture: a vertically-oriented dynasty, represented in each generation by just one exponent, with the authority passed from the father to one of his sons only. According to the story told by the Gesta, the history of the ruling house began with Álmos, said to be a descendant of Attila the Hun, being elected prince; this act was complemented by the oath made by the Hungarian magnates whereby they would always have a prince "de progenie Almi ducis" as their ruler. ${ }^{104}$ In reality, however, the anonymous author tells us that Álmos's future reign was announced still before his birth in his mother's prophetic dream heralding that famous kings would be

102 See György Györffy, Święty Stefan I. Król Węgier i jego dzieto, trans. Tomasz Kapturkiewicz (Warsaw, 2003), $66 \mathrm{ff}$. When considering the Arpads' tenth-century succession practice, references are made to Constantine's account concerning the throne succession system of the Pechenegs. As the emperor remarks, the right to wield monarchal rule was exclusively vested to the members of a clearly singled-out governing kin - defined in terms of a relatively extensive blood-related group whose representatives, descending from its various lines, take over the power one after the other, in a sequence: after the death of the ruler, the throne is always assigned to one of his cousins, who comes from another branch of the dynasty. It is worth bearing in mind, though, that Constantine's 'Hungarian' record as such comprises no direct references to the succession model that functioned among the Pechenegs; cf. Constantine Porphyrogenitus, De administrando, chap. 37, p. 167; see Gyula Kristó, Die Arpaden-Dynastie. Die Geschichte Ungarns von 895 bis 1301 (Budapest, 1993), 41 ff.; idem, Hungarian History in the Ninth Century (Szeged, 1996), $159 \mathrm{ff}$. For the rules of power succession among nomadic peoples, mainly however with respect to a later period, see also: Joseph Fletcher, 'Turco-Mongolian Monarchic Tradition in the Ottoman Empire', in Ihor Ševčenko and Frank Sysyn (eds.), Eucharisterion: Essays Presented to Omeljan Pritsak on his Sixtieth Birthday by his Colleagues and Students, 2 vols. (Harvard Ukrainian Studies, iii/iv, 1979/80), i, 236-51.

${ }^{103}$ See Wincenty Swoboda, 'Anonymus notarius Belae regis Hungariae', in Gerard Labuda and Antoni Gąsiorowski (eds.), Stownik starożytności stowiańskich. Encyklopedyczny zarys kultury dawnych Stowian od czasów najdawniejszych do schytku XII wieku, vii, pt. 2: Suplement A-C (Wrocław, 1986), 365-7.

${ }^{104}$ P. magistri, qui Anonymus dicitur, Gesta Hungarorum, ed. Emil Jakubovich, in Scriptores Rerum Hungaricarum tempore ducum regumque stirpis Arpadianae gestarum (hereafter: SS rer. Hungar.), i (Budapest, 1937), chaps. 5-6, pp. 39-41. 
begotten from her reins. ${ }^{105}$ Álmos subsequently made his only son Árpád prince. ${ }^{106}$ Once Árpád died, the authority was taken over by his only son Zolta who subsequently, three years before his own death, made his only son Taksony prince and handed the rule of Hungary over to him. ${ }^{107}$ Taksony begot Géza who became the fifth prince of Hungary. ${ }^{108}$ The anonymous author's exposition of the Hungarian history offered no room for the relatives of the ruling princes descending from the dynasty's other branches - including Phalitzis, mentioned by Constantine Porphyrogenitus as a ruler of the Hungarians. ${ }^{109}$

It is difficult to tell exactly which historic period corresponds with the compilation of the list of rulers recorded by Gesta Hungarorum, and of its underlying vision of the 'dynastic' past of the ruling house. This vision appears to fundamentally differ from the image of the Arpads offered us by Constantine Porphyrogenitus's account - an extensive blood-related group whose all members, and not just those of a single distinguished line, were equally entitled to the rights to partake in the monarchal power. It is possible, though, that the origins of the transformation of the dynasty ruling Hungary into a narrow, internally hierarchised familial structure were associated with the actions aiming at a centralisation of the monarchal authority and introduction of new throne succession principles referring to the idea of filial succession, carried out in the second half of the tenth century after the Lechfeld defeat by Taksony himself, or perhaps by his son Géza, the first Christian ruler of Hungary. ${ }^{110}$ Not much is known about the circumstances of Géza's accession to the throne after Taksony's death. Consequently, it is difficult to resolve to what extent his takeover of the succession after his father was related to the change in the ways the ruling house was perceived, and to the shaping

105 Ibidem, chap. 3, p. 38; see Lesław Spychała, Studia nad legenda dynastyczna Arpadów. Między pulpitem średniowiecznego skryby a "warsztatem" wspótczesnego badacza (Wrocław, 2011).

${ }^{106}$ P. magistri Gesta Hungarorum, chap. 13, p. 52.

${ }^{107}$ Ibidem, chap. 53, p. 106; chap. 57, p. 114.

${ }^{108}$ Ibidem, chap. 57, p. 116.

${ }^{109}$ Although the anonymous author mentions the sons of a certain Hulec, who is once called Álmos's uncle and elsewhere, Árpád's uncle, the position of these female-line relatives of the ruling princes did not divert from the one the other leaders, subject to them, held at the time, and by no means gave the right to participate in the governance; see ibidem, chap. 7, p. 41; chap. 33, p. 74 .

${ }^{110}$ Cf. Györffy, Święty Stefan, 60 ff. 
of new ideas about the nature of dynastic authority. ${ }^{111}$ However, as for Géza himself, the evidence indicating that he took efforts in view of solidifying the new model of filial succession, breaking with the traditional vision of monarchal eligibility owed to all the relatives of the ruler, proves to be much more explicit.

In this context, the events related to the conflict that occurred after Géza's death in 997 between his son, and successor, Stephen I and Prince Koppány are worth recording. In Simon of Kéza's Gesta Hungarorum, Stephen's victory over Koppány is combined with the piece of news stating Stephen's defeat of his uncle who ruled Transylvania, whom he had imprisoned, and his victory over Kean, the ruler of the Bulgarians and the Slavs. ${ }^{112}$ The account of the fourteenth-century chronicler's composition, which probably refers to a much older (now lost) source, and does not arouse any serious objections with respect, at least, to the general course of the events it describes, ${ }^{113}$ allows us to infer that there was something peculiar to the dispute with Koppány,

${ }^{111}$ It is worth noting here, however, that the list of rulers known from the work in question, who took over the power father-to-son, sequentially: Álmos Árpád - Zolta - Taksony - Géza, appears in no other Hungarian historiograhic work. The kinship bonds linking the figures named by the anonymous author are also mentioned in the genealogical deduction of the Arpads contained in the fourteenth-century chronicle composition; there is no mention, however, that Zolta would exercise the rule after Árpád, and subsequently pass it over to Taksony; see Chronici Hungarici Compositio saeculi XIV, ed. Alexander Domanovszky, SS rer. Hungar., i, chap. 26, p. 285. Characteristic of the Hungarian historiographic tradition is, essentially, considerable imprecision in presenting the dynasty's earliest history, particularly with regard to the succession to the throne after Árpád's death. All the same - seemingly, not the least important thing - both the Gesta Hungarorum by Simon of Kéza (1280s) and the fourteenth-century chronicle composition mark the beginning of the uninterrupted chain of filial successions only with the rule of Taksony, Géza's father. None of these sources indicates, however, the circumstances in which he seized power and who preceded him on the throne; see Simonis de Keza Gesta Hungarorum, ed. Alexander Domanovszky, SS rer. Hungar., i, chap. 42, p. 171; chap. 43, p. 172; Chronici Hungarici Compositio, chap. 63, p. 311. The Zagreb Chronicle is the only one to present Taksony as a son and direct successor of Árpád; see Chronicon Zagrabiense cum textu Chronici Varadiensis collatum, ed. Imre Szentpétery, SS rer. Hungar, i, 206.

112 Simonis de Keza Gesta Hungarorum, chap. 43, p. 172.

113 See Dániel Bagi, 'Problematik der ältesten Schichten der ungarischen Chronikkomposition des 14. Jahrhunderts im Lichte der ungarischen Geschichtsforschung der letzten Jahrzehnte - einige ausgewählte Problemstellen', Quaestiones Medii Aevi Novae, xii (2007), 105-27. 
which made it different from Stephen's other war expeditions. The chronicle in question makes it apparent that after Géza's death, Koppány resolved to marry his widow, kill Stephen, and subjugate his kingdom to his rule. ${ }^{114}$

The story told by this source does not clearly suggest what the cause of Koppány's monarchal aspirations was. What is only said is that his father Zerind the Bald wielded a ducatus when Géza was alive, whilst Koppány himself was prince of Somogy. ${ }^{115}$ It nonetheless seems that his position, and that of his father too, diverted from the one that was due within the Hungarian polity structures to the other, semi-sovereign local rulers, such as Gyula of Transylvania or Ajtony, with whom Stephen had to wrestle as he wanted to submit them to stricter control from the central authority. ${ }^{116}$ As can be inferred from the chronicler's words, indicating that Koppány's intent was "per incestuosum copulare connubium" Géza's widow, the prince standing up against Stephen must have been related with him by close ties of kinship. ${ }^{117}$ It may therefore be supposed that by opposing Stephen's succession after Géza's death and declaring his own aspirations for power, Koppány referred to the old ideas of a communal nature of the authority wielded by the ruling house, the rights to which would be owed on equal terms to all the descendants of Árpád, rather than to one such descendant, appointed by the preceding ruler. ${ }^{118}$

Stephen's decision to designate his nephew Peter Orseolo as the successor to the throne in 1038, after the death of his son Emeric, thus omitting his cousin and closest male-line relative Vazul, came as a complementation to the transformation of the dynastic awareness among members of the dynasty ruling Hungary. This process, initiated by Géza, if not by Taksony, led to forcing the dynasty's lateral-line representatives out of the circle of those entitled to power. The identity of a dynasty being thus formed by Stephen was, therefore, to be determined no more by affiliation with one distinguished line of the Arpads, descendants of Taksony, but, instead, the closest kinship, including female-line, with the ruler at power. There was no room

${ }^{114}$ Chronici Hungarici Compositio, chap. 64, p. 313; see Kristó, Die Arpaden-Dynastie, $60 \mathrm{ff}$.

${ }^{115}$ Cf. Györffy, Święty Stefan, 139-40.

116 Ibidem, 202 ff.; Kristó, Die Arpaden-Dynastie, 69 ff.

117 Chronici Hungarici Compositio, chap. 64, p. 313.

118 Cf. Györffy, Święty Stefan, 139 ff.; Kristó, Die Arpaden-Dynastie, 60 ff. 
designed for the remaining relatives of the king: Vazul, who would not be ready to acquiesce and sought to exercise his rights, was blinded, and his sons condemned to exile. ${ }^{119}$ The promotion to the throne a few years later, in 1041, of Samuel Aba, Stephen's sister's husband, by the magnates rebelling against Peter, is indicative of that the new concept of dynasty, implying a radical breakage with the previous dynastic order, could count on comprehension and acceptance by, at least, a part of the political elite. ${ }^{120}$

As a conclusive outcome, the actions taken by Stephen did not cause reinforcement in Hungary of a new 'dynastic' model of authority. In the face of the crisis that affected the Hungarian monarchy in the 1040s, most of the magnates decided to become affiliated with the lateral line of the Arpads, and to call Vazul's sons back from their exile. ${ }^{121}$ The result was that, as they were back home, the old concepts of authority as a common heritage of the entire ruling house started shaping anew the political reality of Hungary and affecting the course of political events, clashing, until the early thirteenth century, against the endeavours repeatedly made by the consecutive kings to restrict the number of those eligible to share power and to ensure the throne's succession solely to their own descendants. This is the way one should see the dynastic disputes occurring in Hungary in the second half of the eleventh century and in the twelfth century, extinguished only in the thirteenth century through the filial succession concept taking hold in the social awareness. ${ }^{122}$

The sparse and, moreover, ambiguous source records offering information on the earliest history of the Piast kin only allow for making very general suppositions with respect to its internal structure. In his chronicle account regarding the division of the country by Duke Mieszko I in 992, followed by its insidious integration effected by his eldest son, Boleslav I the Brave, and his expulsion of his stepmother

119 Annales Altahenses Maiores, ed. Wilhelm von Giesebrecht and Edmund L. B. von Oefele, MGH SS rer. Germ. in us. schol., iv (Hanover, 1890), 24; Herimanni Augiensis Chronicon, ed. Georg H. Pertz, MGH Scriptores, v (Hanover, 1844), 123; see Györffy, Święty Stefan, 449 ff.; Kristó, Die Arpaden-Dynastie, 80.

${ }^{120}$ Annales Altahenses Maiores, 29; Annales Hildesheimenses, 45; Herimanni Augiensis Chronicon, 123; see Kristó, Die Arpaden-Dynastie, 84 ff.

${ }^{121}$ Herimanni Augiensis Chronicon, 126; G. Kristó, Die Arpaden-Dynastie, 87 ff.

122 See Zbigniew Dalewski, 'Was Herrscher taten, wenn sie viele Söhne hatten - zum Beispiel im Osten Europas', in Jussen (ed.), Die Macht des Königs, 133 ff. 
and half-brothers, Thietmar of Merseburg seems to suggest that the rationale behind Mieszko's succession ordinances could have been determined by his conviction that all his sons had an equal right to power belonging to him. ${ }^{123}$ It might be thus inferred that the Piasts also perceived their authority as, in a way, shared property of the whole dynasty in which all its members could, and indeed ought to, participate to an identical degree. The document called Dagome iudex (survived only in the form of a summary), which - as is known mentions Mieszko I and his second wife Oda, and the couple's sons: Mieszko and Lambert, excluding Boleslav, born out of Mieszko I's first marriage, ${ }^{124}$ outlines the possible conjecture that already at the very origins of the Piast family we might encounter a hierarchically diversified dynastic structure within which the monarchal rights would only be vested to its selected representatives. There is a variety of meanings potentially ascribable to Mieszko I's decision to donate his state to St Peter mentioned in the document in question; there is seemingly no point dealing now with the details of the related discussions. ${ }^{125} \mathrm{It}$ would be awkward not to notice, though, that taking account only of the sons born out of his marriage with Oda in the deed of donation of Mieszko's dominion to the benefit of St Peter, leading to the contraction of a special bond between them and the Saint, placed them in a privileged position against their elder stepbrother and, let us add, his offspring - as Boleslav had had two sons by then, Bezprym and Mieszko. ${ }^{126}$ As a result, the conjecture seems highly plausible that the

123 Thietmar, iv. 58, pp. 196-8; cf. Andrzej Pleszczyński, 'Początek rządów Bolesława Chrobrego', in Mateusz Goliński and Stanisław Rosik (eds.), Viae historicae. Księga jubileuszowa dedykowana Profesorowi Lechowi A. Tyszkiewiczowi w siedemdziesiąta rocznice urodzin (Wrocław, 2001), 217-32.

${ }^{124}$ Die Kanonessammlung des Kardinals Deusdedit, i: Die Kanonessammlung selbst, ed. Viktor Wolf von Glanvell (Paderborn, 1905), iii. 199, p. 359; Brygida Kürbis, 'Dagome iudex - studium krytyczne', in Kazimierz Tymieniecki, Gerard Labuda, and Henryk Łowmiański (eds.), Początki państwa polskiego. Księga tysiąclecia, 2 vols. (Poznań, 1962), i, 363-424.

${ }^{125}$ For a recent reference, see Dariusz A. Sikorski, Kościót w Polsce za Mieszka I $i$ Bolestawa Chrobrego. Rozważania nad granicami poznania historycznego (Poznań, 2011), 209-75.

${ }^{126}$ Cf. Jacek Banaszkiewicz, 'Mieszko I i władcy jego epoki', in Jan M. Piskorski (ed.), Polska Mieszka I. W tysiąclecie śmierci twórcy państwa i Kościoła polskiego $25 \mathrm{~V}$ 992 - 25 V 1992 (Poznań, 1993), 104 ff.; Roman Michałowski, 'Christianisation of Political Culture in Poland in the 10th and Early 11th Century', in Halina 
issuance of the document by Mieszko was related to the plans to hand over the authority over the St Peter-owned state only to Mieszko's younger sons, and to have Boleslav and his sons removed beyond the framework of the ducal dynasty. ${ }^{127}$

Two brothers of Mieszko I appear in the sources: one, unknown to us by name, is known to have been killed in the fights with Wichmann Billung and the Veleti; ${ }^{128}$ the other, Czcibor, defeated Margrave Hodo's army in the battle of Cedynia (Zehden). ${ }^{129}$ The mentions of them implicate questions about the role they could have had in the authority structures, and about the character of their relationships with Mieszko. Uncertain hypotheses is what remains in this matter. Thietmar's account on Mieszko's division of the state, on the one hand, and the duke's strivings for finding a specific ideological justification for the plans to ensure succession only to his younger sons, identifiable in Dagome iudex, on the other, seem to point out that the conviction about the rights to authority vested in all the sons of the ruler was characteristic of the Piast tradition. If this is an apt conclusion, then the supposition is legitimate that these rights should have related not only to the generation of Mieszko's sons but also to his own generation, his own brothers being thus included as well. The source records informing on both of Mieszko's brothers do not mention any conflicts between Mieszko and either of them; on the contrary, they prove that the men strictly collaborated with one another. Should it therefore be assumed that their participation in power did not only boil down to fulfilment of the military functions on Mieszko's order, but there was a much wider, monarchal range to it - ensuing not so much from their dependency upon Mieszko's authority as from their membership in the ruling family? It is worth reminding on this occasion that while mentioning the division carried out by Mieszko, Thietmar pointed out that the duke had his state divided among the several - Mieszko died "relinquens regnum suimet plurimis dividendum"

Manikowska and Jaroslav Pánek (eds.), Political Culture in Central Europe (10th-20th Century), i: Middle Ages and Early Modern Era (Prague, 2005), 32, 45.

127 See Gerard Labuda, 'Znaczenie prawne i polityczne dokumentu Dagome iudex', Studia i Materiaty do Dziejów Wielkopolski i Pomorza, xiii (25) (1979), 82-100; idem, 'Prawne i polityczne aspekty dokumentu Dagome iudex', in idem, Studia nad początkami państwa polskiego, 2 vols. (Poznań, 1987-8), ii, 240-63.

128 Widukind, iii. 66, p. 141.

129 Thietmar, ii. 29, pp. 74-6. 
- albeit further on a mention is only made of Boleslav expelling his half-brothers. Thus, was the circle of successors limited exclusively to Mieszko's sons, and could it possibly extend to his other relatives?

The surmise that also in the case of the first Piasts, we may deal with a broader blood-related group that cherished the memory of its own kinship bonds and the ensuing rights to participate in the ducal authority, seems to be supported by the events related to another division of the Piast dominion, carried out in 1032 by order of Emperor Conrad II. King Mieszko II of Poland had at that point to agree to share his power not only with his brother Otto but also with a certain Theodoric whom the Hildesheim annalist defined as his patruelis. ${ }^{130}$ There is a general consent that this figure ought to be seen as a son of one of the sons of Mieszko I and Oda, expelled forty years before then from Poland. ${ }^{131}$ Theodoric's sudden appearance in 1032 is perhaps not explainable solely in terms of the emperor's intervention. It may rather be inferred that there was an underlying belief, deeply rooted in the ideas of the community subject to the Piasts' authority, that the monarchal entitlement was owed to all the members of the Piast kin. Whether it only referred to the offspring of Mieszko I, or extended to a wider circle of Piast relatives, remains an open question.

Given the context, the events related to the assumption of the throne by Boleslav the Brave's son, Mieszko II in 1025 seem to be worth special attention. ${ }^{132}$ Mieszko's distinguished position at his father's side, as noticed by Thietmar, ${ }^{133}$ allows the supposition that he was handed over the power after his death following the decisions made by Boleslav: it was Mieszko that the latter decided to entrust the rule of the Piast monarchy to, omitting the remaining sons. ${ }^{134}$ It

130 Annales Hildesheimenses, 37: “imperator ... eique et eius [i.e. Mieszko's] patrueli cuidam Thiedrico regnum, quod ipse solus ante possederat, divisit."

131 See Kazimierz Jasiński, Rodowód pierwszych Piastów (Warsaw and Wrocław, 1992), 126-7.

132 See Zbigniew Dalewski, 'Koronacja Mieszka II', in Joanna Sobiesiak et al. (eds.), Historia narrat. Studia mediewistyczne ofiarowane Profesorowi Jackowi Banaszkiewiczowi (Lublin, 2012), 111-27.

133 See, e.g., Thietmar, vi. 90, pp. 380-2; vii. 10, pp. 408-10; vii. 17, p. 418; vii. 59, p. 472 .

${ }^{134}$ Boleslav's plans to ensure the succession to Mieszko probably had also to do with the information, provided by Peter Damiani, that the conventual community of St Romuald in Pereum accepted as a member an unnamed son of a Polish ruler, who is usually identified with Bezprym; Petri Damiani Vita beati Romualdi, 
can be inferred, however, that Boleslav's actions were not limited to determining the rules of throne succession after his death: more farfetched than that, they were intended to bring about a fundamental reconstruction of the ruling family's identity and, essentially, to create a new dynasty that would be clearly separated from a broader Piast blood-related group - one wherein monarchal authority would be passed father-to-son, in each generation.

These plans, which meant a radical breakage with the previous ways in which authority and power was perceived, were related, to a considerable degree, to the endeavours Boleslav undertook to win the crown as king for himself in the early eleventh century. ${ }^{135}$ The concept of sacred bases of kingship thoroughly altered the relationships between members of the Piast kin, and promoted the king, distinguished by the anointment and called to the throne by God himself, over his remaining relatives, close or distant, providing ideological grounds for his exclusive rights to wield power - the latter previously forming common property of the entire family. Establishing a kinsmanship between the new, 'royal' dynasty Boleslav designed to build and the imperial house was meant to reconfirm monarchal monopoly of the former. Contracted most probably in 1013, Mieszko's marriage to Richeza - Otto III's niece and relative of Henry II, to be sure - introduced the Piasts, indeed, into the circle of the mightiest families of the Reich, ${ }^{136}$ and more: to no lesser extent, it determined the position of Mieszko himself and his offspring born to this marriage in their relations with their brothers or distant relatives. Giving Mieszko and Richeza's son, born 1016, the imperial name of Charles ${ }^{137}$ makes one suppose that it was the awareness of imperial

ed. Giovanni Tabacco (Fonti per la storia d'Italia, 94, Rome, 1957), chap. 26, p. 55: "Habebat [i.e. Romuald] autem equum satis egregium, quem sibi Busclavi Sclavonici regis filius dederat, factus ab eo monachus”; see Jasiński, Rodowód, 106-7.

${ }^{135}$ See Zbigniew Dalewski, 'Dlaczego Bolesław Chrobry chciał koronować się na króla?’, in Józef Dobosz, Marzena Matla, and Leszek Wetesko (eds.), Gnieźnieńskie koronacje królewskie i ich środkowoeuropejskie konteksty (Gniezno, 2011), 21-41.

${ }^{136}$ Jasiński, Rodowód, 114 ff.; cf. Andrzej Pleszczyński, Niemcy wobec pierwszej monarchii piastowskiej (963-1034). Narodziny stereotypu. Postrzeganie i cywilizacyjna klasyfikacja władców Polski $i$ ich kraju (Lublin, 2008), $237 \mathrm{ff}$.

${ }^{137}$ Casimir's second name is mentioned only by Gallus Anonymus's chronicle, but there is no reason at all to doubt its reliability in this respect; Galli Anonymi Cronicae et gesta ducum sive principum Polonorum, ed. Karol Maleczyński (Monumenta Poloniae Historica, N.S., i, Cracow, 1952), i. 17, p. 40; cf. Stanisław Kętrzyński, 
descent that formed, in Boleslav's design, one more foundation along with the royal anointment idea - whereupon the new dynastic order he was building would be erected. The underlying principle of this order was that the authority would only be vested in a single line of the ruling house - royal, by anointment, and imperial, by descent.

It would certainly be somewhat tricky to claim that the actions taken by Boleslav proved completely successful. A mere few years after his death, the rule of his successor whom he had appointed collapsed. ${ }^{138}$ As both brothers of Mieszko II - the elder, stepbrother Bezprym, and the younger, Otto - brought an action against him, and his cousin Theodoric laid claims to the throne, at a later date, it may be said that in spite of Boleslav's efforts aiming at altering the existing dynastic model, the traditional understanding of monarchal authority in terms of common property of the entire ruling house continued to exert a material impact on the ways in which the monarchal power was perceived, and heavily informed the political decisions. It made its presence felt, after all, not only in the 1030s, significantly contributing to the fall of Mieszko Il's royal rule, but also determined the ways the Piasts perceived their monarchal rights, and the throne succession issue was settled in the following centuries. The failure of Boleslav the Brave's plans, similarly to Stephen I's or Vladimir the Great's designs, which had a similar purpose behind them, ought not to blot out the fact that the actions they undertook in view of transforming the kins ruling in Poland, Rus' and Hungary into narrow hierarchised dynastic structures have heavily influenced the memory of their own past, and, in the long run, led to a fundamental alteration of their identity. The dynastic tradition of the Piasts, as recorded in Gallus Anonymus's chronicle, and probably conceived shortly after the crisis of the $1030 \mathrm{~s}^{139}$, has preserved the memory of the imperial descent and

'Karol Wielki i Bolesław Chrobry', Przeglad Historyczny, xxxvi (1946), 19-25; Jacek Hertel, Imiennictwo dynastii piastowskiej we wcześniejszym średniowieczu (Toruń, 1980), 122-3; Jasiński, Rodowód, 129-30.

${ }^{138}$ Danuta Borawska, Kryzys monarchii wczesnopiastowskiej $w$ latach trzydziestych XI wieku (Warsaw, 1964); Gerard Labuda, Mieszko II król Polski (1025-1034). Czasy przełomu $w$ dziejach państwa polskiego (Cracow, 1992), $78 \mathrm{ff}$.

${ }^{139}$ See Jacek Banaszkiewicz, 'Tradycje dynastyczno-plemienne Słowiańszczyzny północnej', in Henryk Samsonowicz (ed.), Ziemie polskie w X wieku $i$ ich znaczenie $w$ ksztaltowaniu sie nowej mapy Europy (Cracow, 2000), 269; Michałowski, 'Christianisation of Political Culture', 45-6. 
name of Boleslav the Brave's grandson and Mieszko II's son, Casimir I the Restorer, remaining tacit about the dynasty's lateral lines, and moreover - similarly to the tales of the origins of the Rurikids and the Arpads, in the Rus' and Hungarian accounts - inscribed the Piasts' history in a dynastic sequence of filial successions, thereby setting the point of reference for the ideas and concepts regarding the appropriate character of the desired prevalent relationships among members of the ruling family.

trans. Tristan Korecki 